\title{
Multiscale Erosion Surfaces of the Organic-Rich Barnett Shale, Fort Worth Basin, USA
}

\author{
Mohamed O. Abouelresh \\ Faculty of Petroleum and Mining Engineering, Suez University, Salah Naesem St., Etaka, Suez 43721, Egypt \\ Correspondence should be addressed to Mohamed O. Abouelresh; omaradh@yahoo.com
}

Received 21 September 2012; Revised 18 March 2013; Accepted 10 April 2013

Academic Editor: Steven L. Forman

Copyright (C) 2013 Mohamed O. Abouelresh. This is an open access article distributed under the Creative Commons Attribution License, which permits unrestricted use, distribution, and reproduction in any medium, provided the original work is properly cited.

\begin{abstract}
The high frequency and diversity of erosion surfaces throughout the Barnett Shale give a unique view into the short-duration stratigraphic intervals that were previously much more difficult to detect in such fine-grained rocks. The erosion surfaces in Barnett Shale exhibit variable relief $(5.08-61 \mathrm{~mm})$ which commonly consists of shelly laminae, shale rip-up clasts, reworked mud intraclasts, phosphatic pellets, and/or diagenetic minerals (dolomite and pyrite) mostly with clay-rich mudstone groundmass. Several factors control this lithological variation, including the energy conditions, rate of relative sea-level fluctuation, rate of sedimentation, sediment influx, and the lithofacies type of the underlying as well as the overlying beds. The erosional features and their associated surfaces make them serve at least in part as boundaries between different genetic types of deposits but with different scales according to their dependence on base level and/or sediment supply. Accordingly, the studied erosion surfaces of the Barnett Shale can be grouped into three different scales of sequence stratigraphic surfaces: sequence-scale surfaces, parasequence-scale surfaces, and within trend-scale surfaces.
\end{abstract}

\section{Introduction}

The classic interpretation of organic-rich shale $(\geq 0.5 \%$ total organic carbon) deposition emphasized continuous hemipelagic deposition in deep, quiet, low energy and stagnant basins, often with a stratified water column. However, Schieber [1] identified laterally continuous erosion surfaces in the Chattanooga Shale and he interpreted them as being the result of wave reworking and erosion of the sea floor. These surfaces are direct indications of major environmental events that may include nondeposition and/or erosion events.

The multiple erosion events, resultant surfaces, and erosion features are common within the coarser clastic rocks and are pivotal in classifying depositional sequences based upon relative sea-level fluctuations. On the other hand, in finegrained sediments, these events are subtle [2], although the identification is important in elucidating and development of the sequence stratigraphic framework for such rocks.

Mud floored erosion in the geologic record is often associated with zones of intensely burrowed sediment; hiatusconcretions and prefossilized organic remains reveal complex cycles of exhumation and reburial associated with erosion (see [3-6]). Of particular significance are intervals of vertically mixed sediment, shells, and nodules associated with this erosion and/or reworking surfaces. Such sediment intervals yield a complete spectrum from in situ to extensively reworked shale clasts, thus allowing detailed reconstruction of the erosion event as an ongoing process; however, not all erosion surfaces are marked by shale clasts [7].

Noteworthy, the erosion surfaces and their resultant lags can provide an indirect measure of processes and palaeogeography that existed immediately preceding and during transgression, a time most commonly characterized by hiatus and erosional vacuity [8]. The erosion surfaces are relatively abundant throughout the Barnett Shale, punctuate the stacking patterns, and may obliterate the record of various strata [9]. However, erosion provides regional bounding surfaces for classifying this $\sim 25$ myr shale.

This work aims to identify the characters of erosion surfaces and their related features in organic-rich shales which occur on multiple scales from different erosional events. Moreover, this work also shows how these surfaces could 


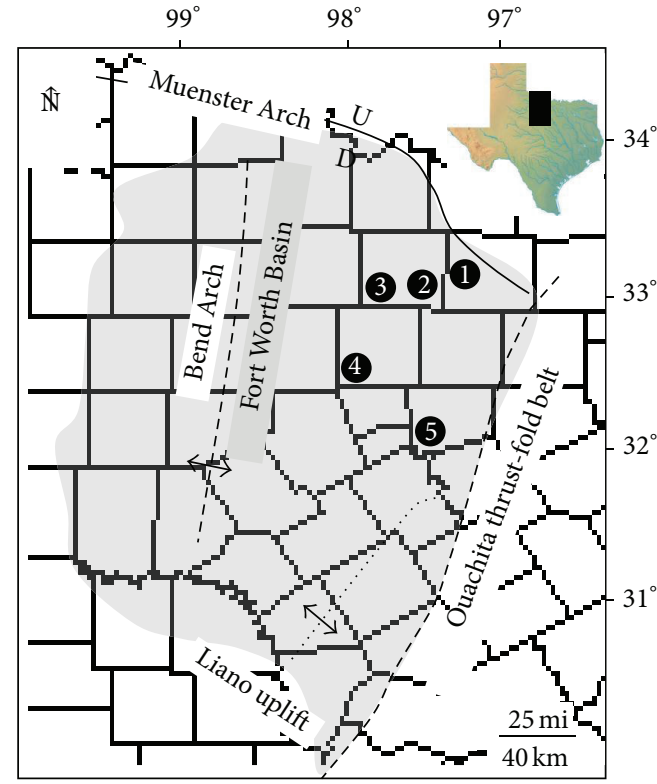

(a)

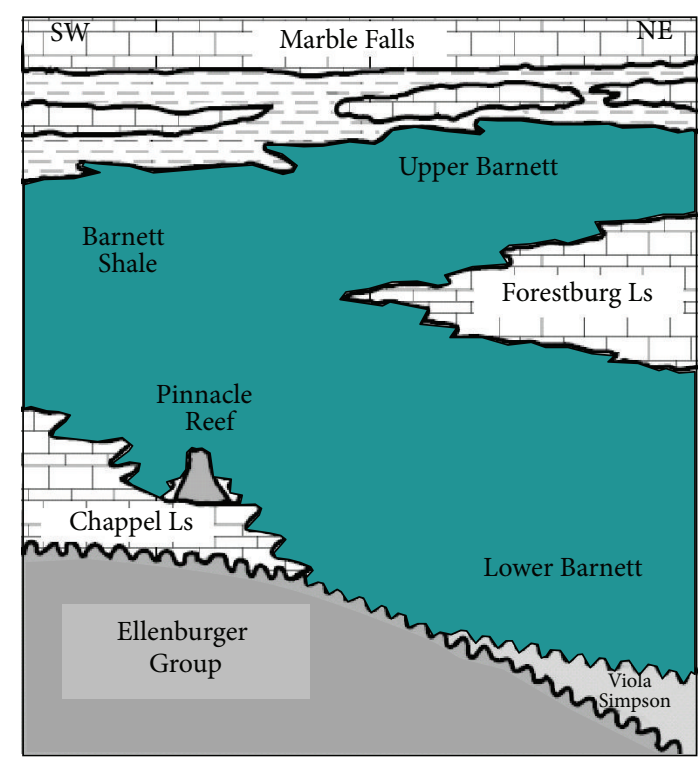

(b)

FIGURE 1: (a) Location map for the Fort Worth Basin showing the distribution of the Barnett Shale (shaded area) and structural and tectonic features; dots refer to the studied wells; 1: John Porter \#3, 2: Sol Carpenter \#7, 3: Adams SW \#7, 4: Sugar Tree \#3, and 5: Spencer Trussell 1-H (modified from [10]). (b) The schematic section shows an interpretation of the Mississippian stratigraphy (modified from [10]).

be used as multiscale stratigraphic surfaces for classifying genetically related fine-grained rocks.

\section{Geologic Setting}

The organic-rich Barnett Shale of Fort Worth Basin, Texas, is a world-class unconventional gas reservoir deposited over a period of 25 million years from 345 to 320 myr [10]. The Fort Worth Basin extends some $322-402 \mathrm{~km}$ from the Red River arch in the north to the Llano uplift in the south (Figure 1(a)). The Bend arch forms the western margin of the basin and the Ouachita thrust front forms the eastern margin. The basin covers approximately $24140 \mathrm{~km}^{2}$. It is one of a series of foreland basins formed along the southern margin of the North American craton during the late Paleozoic Ouachita orogeny [11-13]. Paleozoic strata comprise almost the entire fill of the Fort Worth Basin. The basin fill thickens to the northeast, into the Oklahoma aulacogen, and thins to the south and west, toward the Llano uplift and the Bend arch, respectively. The Barnett Shale also thins to the west over the Bend arch where it interfingers with the Chappel Formation [14-17].

Following an extensive early Paleozoic transgression, erosion removed all of the Silurian and Devonian strata from the Fort Worth Basin [14]. The Barnett Shale was the first unit to be deposited when the seas returned (Figure 1(b)). The Barnett Shale was deposited on the karsted surface of the Ellenburger Group over a wide area [16]. Older stratigraphic studies suggest that most of the Barnett Shale accumulated either on a normal marine shelf [14] or in a relatively shallow, starved basin under euxinic conditions [16]. However, more recent work interprets the Barnett Shale in the Fort Worth Basin as deep-water slope-to-basin deposit $[18,19]$. The relatively low energy and deep water environment, distant from a terrigenous sources, is inferred for the lower Barnett Shale. Whereas, depositional environment for the upper Barnett Shale is inferred to be shallower, proximal, welloxygenated compared to the lower facies $[9,18]$.

Interestingly, the organic-rich Barnett Shale is characterized by a prolonged history of deposition and erosion due to frequent changes in relative sea level especially in the upper part; these fluctuations match with those proposed by Haq and Schutter [20] for the Late Mississippian. This type of fluctuation generated a variety of depositional, nondepositional, and erosional features, which have been placed within a sequence stratigraphic framework $[9,21]$.

\section{Data and Methodology}

The small grain size $(<62 \mu \mathrm{m})$, subtle textural variations, lack of differences in erosion styles, and the gray to black color mean that the organic-rich Barnett Shale is difficult to characterize using conventional sedimentological techniques [22]. In this work, five continuous cores from the Barnett Shale (John Porter \#3 (JP) in Denton County, Sol Carpenter H\#7 (SC), Adams SW\#7 (ASW) in Wise County, Sugar Tree \#1 (ST) in Parker County and Spencer Trussell \#1-H in Johnson County, Texas, USA) were studied.

Thirty three (33) thin sections collected from these cores represent a wide range of different erosion surfaces throughout the Barnett Shale. These thin sections were scanned using 

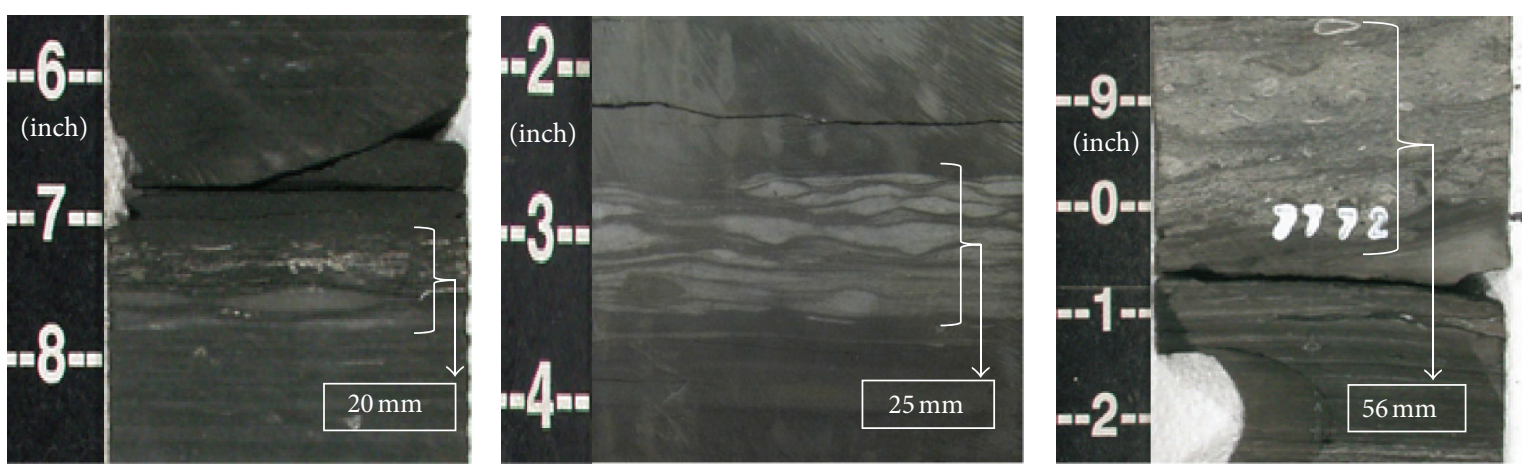

Figure 2: Core photos show different reliefs of erosion surfaces and their related features ranging from $20 \mathrm{~mm}$ to $56 \mathrm{~mm}$.

an Epson, 48-bit color, 4800 dpi scanner to give a higher resolution image than what can be obtained either from hand specimens or even under polarizing microscope. Core samples and thin sections observations were recorded and photographed in detail to shed light on the different characteristics of the erosional surfaces.

\section{Results}

The detailed investigation of erosion surfaces throughout the Barnett Shale showed that these surfaces are part of zones vertical reliefs ranging from a few millimeters to several centimeters (Figure 2) as a result of differential erosion; considering that prior to compaction, this relief would have been up to $90 \%$ greater [23]. These zones consist of vertically mixed components within clay-rich mudstone groundmass. The most common components of the erosion surfaces include surface nature, shelly laminae, shale rip-up clasts, reworked intraclasts, phosphatic pellets, and diagenetic minerals (dolomite and pyrite). The following is a detailed description for each of these features which are also summarized in Table 1.

\subsection{Surface Nature}

4.1.1. Description. The nature of erosion surfaces is frequent and identifiable on thin sections and core samples. The detailed investigation of the studied cores showed that these surfaces exhibit different shapes including (Table 1) sharp straight (though sharp irregular has been seen) (Figure 3(a)), scour, irregular (Figure 3(b)), and gradational upper contact (Figure 3(c)). In some cases the surface may down-cut into older deposits (Figure 3(d)). The lack of burrowing with most of lower sharp contacts is common.

4.1.2. Interpretation. The lithology changes marked by erosion surface could be associated with reworking and winnowing of the preexisting deposits as a result of prevailing tide, wave, or storm action [24]. However, these surfaces may represent a hiatus or periods of low sedimentation rate and/or sediment starved conditions. The sharp contact (Figure 3(c)) reflects an erosion event associated with a sudden sea-level fluctuation $[1,7]$ whereas the displacement of some surfaces into the underlying lithology is interpreted as an effect of soft sediment deformation processes (Figure 3(d)). On the contrary, the absence of soft sediment deformations below the sharp surface (Figure 3(a)) suggests the eroded shale was of firm consistency [1]. The sharp nature of the erosion surface suggests that erosion may have removed the mixed layer close to the sediment-water interface prior to deposition of the overlying unit. However, when the sharp contact marks the top of an erosion zone (Figure 3(a)), then sediment starvation was most likely and probably bottom currents that affected this location. Inversely, if the sharp nature is located at the base of the erosion zone (Figure 3(c)), then a sudden subsidence or a fall in sea level would be expected and the winnowed materials would be transported down-dip during a transgression. The organic-rich shale interval with sharp base is more erosional resistant due to the higher organic content [7]. The absence of burrowing along most of lower sharp surfaces suggests that these surfaces are not associated with a prolonged depositional hiatus and that erosion of the underlying sediments was immediately followed by, if not synchronous with, deposition of the overlying lithofacies blanket.

\subsection{Shelly Laminae}

4.2.1. Description. shelly laminae refer to dense concentrations of thin-walled, coalesced fragments, grain to grain contacts, and broken and disarticulated shells which are common in both upper and lower Barnett Shale $[9,21]$. The laminae range to a maximum thickness of $15 \mathrm{~mm}$ (Table 1), with most between 1 and $3 \mathrm{~mm}$. Surfaces are gently curved; bedding-parallel mantled the underlying sharp irregular to straight erosion surface and blanketed gradationally by siliceous noncalcareous to calcareous mudstone facies (Figures 4(a) and 4(b)). Shelly laminae of the Barnett Shale are composed mainly of bivalves, bryozoans, brachiopods, filling branch mollusks, and echinoderms with mainly calcite filling (Figure 4(c)).

4.2.2. Interpretation. Shelly laminae represents a condition of low sediment supply [25] due to the dense compacted shell fragments (Figure 4(a)); however, the rapid accumulation 
TABLE 1: Summary of the erosional features associated with the erosion surfaces.

\begin{tabular}{|c|c|}
\hline Relief & Ranges between $5 \mathrm{~mm}$ and $60 \mathrm{~mm}$ with an average $19 \mathrm{~mm}$. \\
\hline Lithology & $\begin{array}{l}\text { Siliceous noncalcareous to calcareous mudstone groundmass, silty laminated, and phosphatic-rich } \\
\text { mudstone. Pyrite is common and rarely dolomitized. }\end{array}$ \\
\hline \multicolumn{2}{|l|}{ Surface nature } \\
\hline Lower & Sharp to irregular, scoured and down-cutting contact. \\
\hline Upper & Sharp, gradational to irregular, rarely disturbed with burrowing. \\
\hline \multicolumn{2}{|l|}{ Matrix components } \\
\hline Shelly laminae & $\begin{array}{l}\text { Very thin }(1-15 \mathrm{~mm}) \text {, singular to multiple, fragmented shelly laminae. Highly compacted (grain to grain } \\
\text { contact), horizontally alignment. The most common types of shell fragments are bivalves, bryozoans, } \\
\text { brachiopods, filling branch mollusks, and echinoderms with mainly calcite filling. }\end{array}$ \\
\hline Shale rip-up clasts & $\begin{array}{l}\text { Mainly flakey-like shapes with straight outlines. Others are rounded to subrounded, with the same } \\
\text { lithology of the underlying facies. Occurs as suspended clasts in the overlying facies. }\end{array}$ \\
\hline Reworked concretions & $\begin{array}{l}\text { In situ sandy-size to transported gravely-size concretions. Rounded, subrounded to irregular clasts. } \\
\text { Slightly to highly compacted and subhorizontally oriented. Shaley to silty and phosphatic internal } \\
\text { lithology. Pyritic effect is very common. }\end{array}$ \\
\hline Phosphatic pellets & $\begin{array}{l}\text { Very common, rounded to subrounded with multiple internal cores, sometimes broken, irregular, rarely } \\
\text { elongated with their long axis parallel to bedding planes. They range in size from less than } 1 \mathrm{~mm} \text { up to } 1 \mathrm{~cm} \text {. } \\
\text { The nuclei of the phosphatic intraclasts may include shell fragments, detrital quartz, and glauconite grains. }\end{array}$ \\
\hline Pyrite & Common as framboidal shape and rarely as fine euhedral crystal. Not in all samples. \\
\hline
\end{tabular}

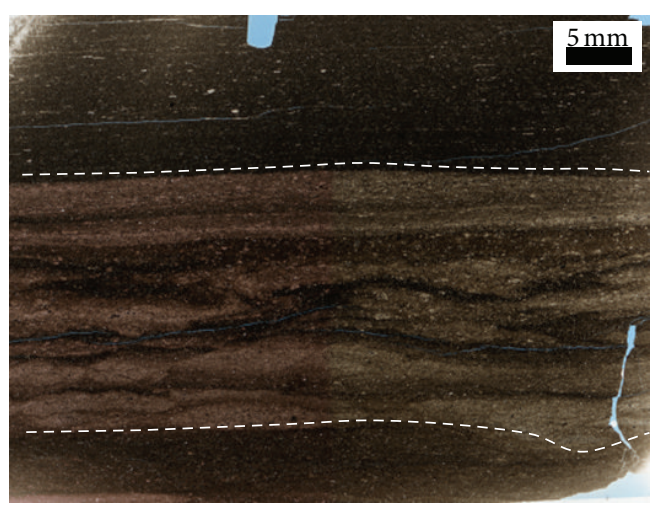

(a)

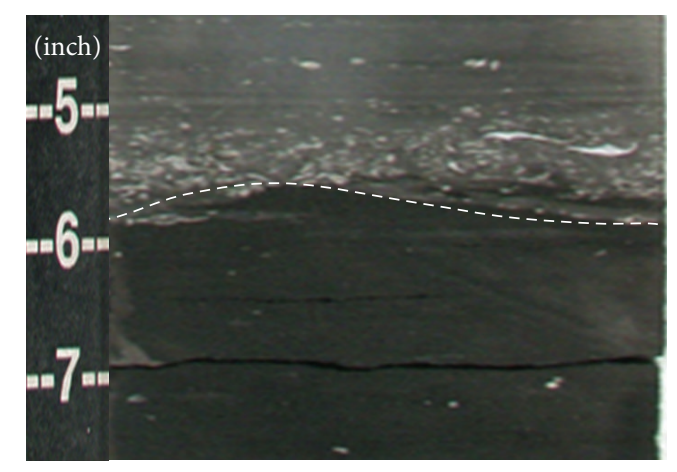

(c)

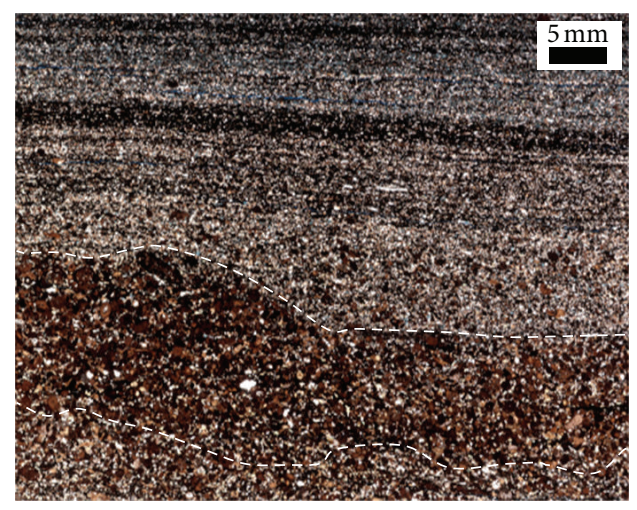

(b)

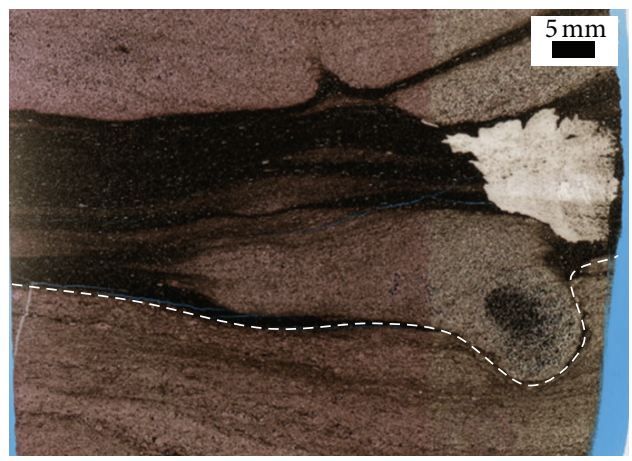

(d)

FIGURE 3: (a) Thin section photo shows upper sharp straight contact and lower scoured contact. (b) Thin section photo shows upper scoured contact and lower irregular contact. (c) Core photo shows lower sharp irregular contact and upper gradational contact. (d) Thin section photo shows lower contact that cut down into underlying facies. 


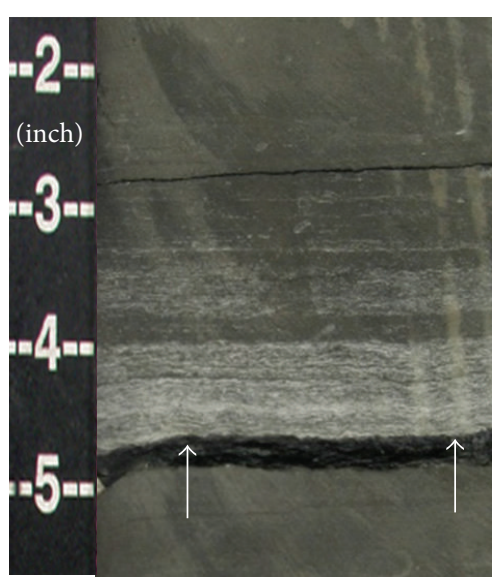

(a)

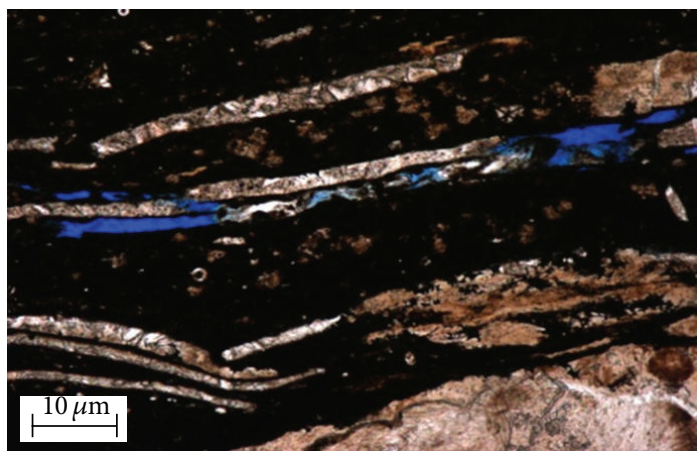

(c)

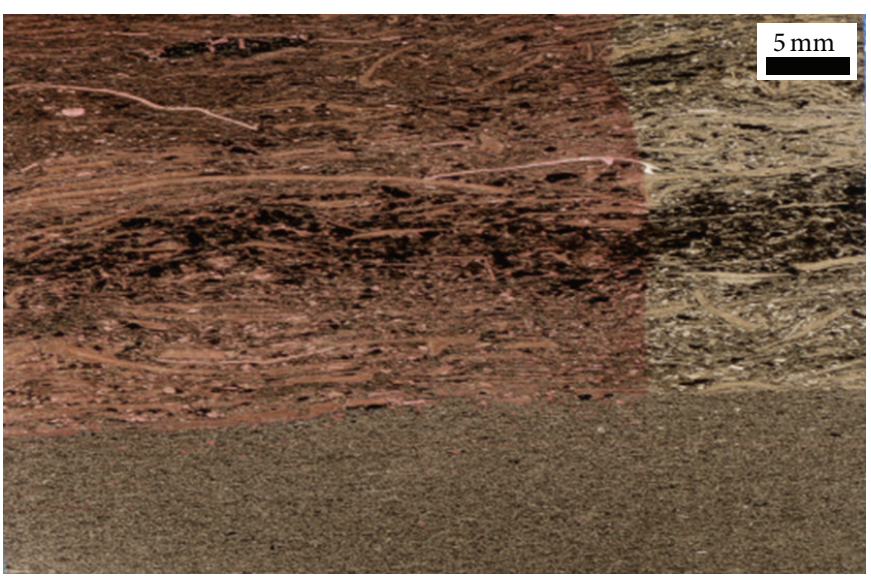

(b)

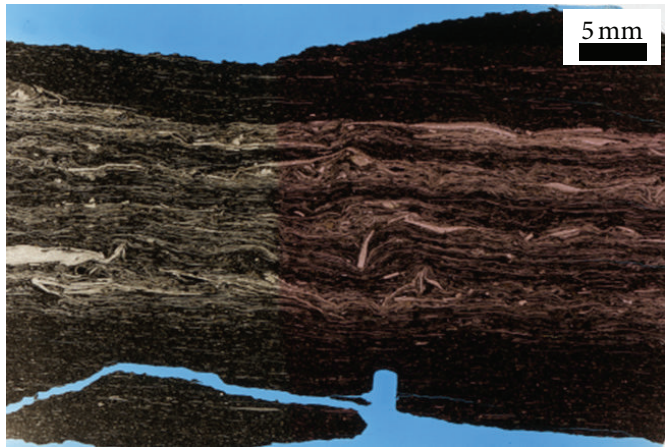

(d)

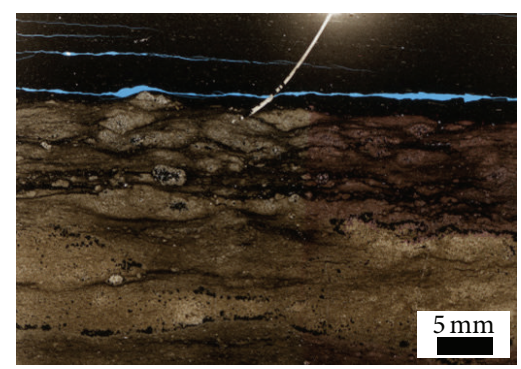

(g)

FIGURE 4: (a) Core photo shows highly compacted shelly laminae (arrows) with lower sharp contact and upper gradational contact. (b) Thin section photo shows lower sharp contact with overlying shelly laminae. (c) Thin section photo shows the shell fragments with calcite filling. (d) Thin section photo shows multiple shelly laminae. (e) Core photo shows shale rip-up clasts with lower and upper sharp contacts. (f) Thin section photo shows scattered shale rip-up clasts (white arrows), note the pyrite filling of some shale rip-up caslt (black arrow). (g) Thin section photo shows rounded to subrounded shale rip-up clasts with lower gradational contact and upper sharp contact.

at the scale of such laminae should be considered [26] especially with the abundance of fossil material. The frequent occurrence of shelly laminae (Figure 4(d)) (regardless of their thickness) is interpreted as resulting either from thin compacted hiatal concentrations or multiple, varying duration episodes of erosion for the underlying deposits, that is, associated with a residual concentration of preexisting and broken fossils [26].

4.2.3. Interpretation. The shale rip-up clasts occur due to the movement of coarser materials down-dip and erosion of the softer seafloor sediments. These clasts are transported and probably then suspended in basal currents and deposited when the current velocity reduced. However, shale rip-up clasts may be transported over considerable distances as evidenced by the rounded to subrounded and/or irregular surfaces (Figure 4(e)). Additionally, the flat and flaky-like shapes of shale rip-up clasts reflect compaction.

\subsection{Reworked Concretions}

4.3.1. Description. Reworked concretions are common features that are associated with the studied erosion surfaces. 


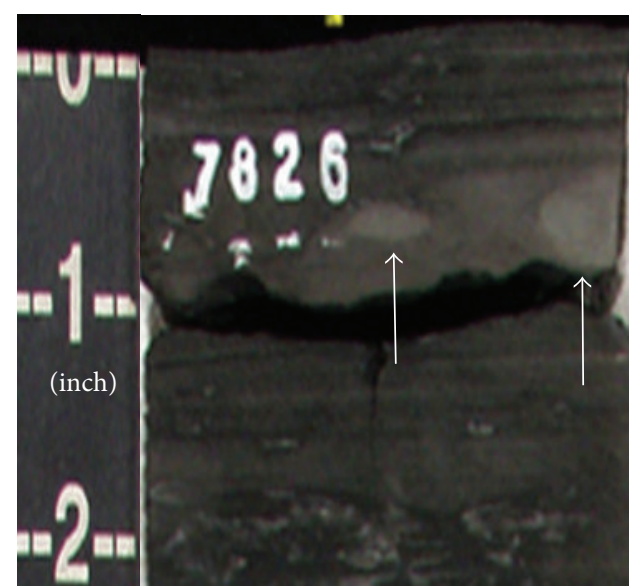

(a)

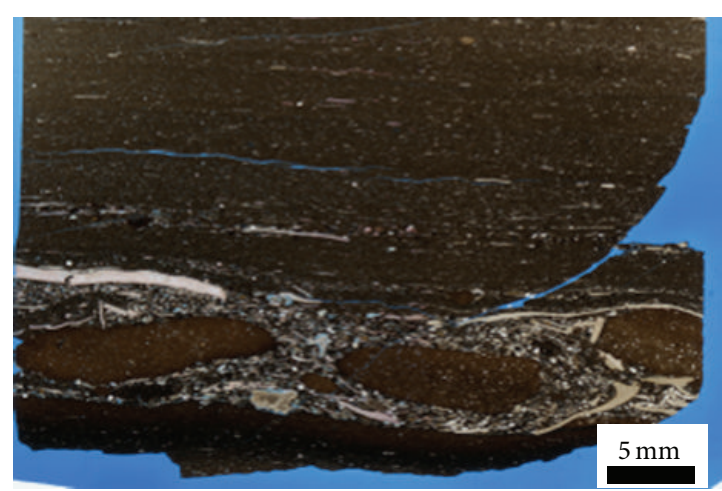

(c)

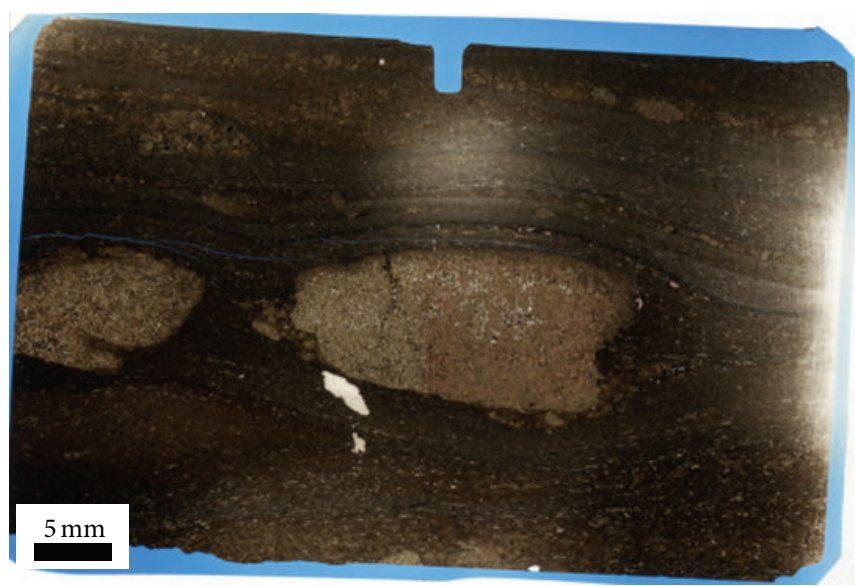

(b)

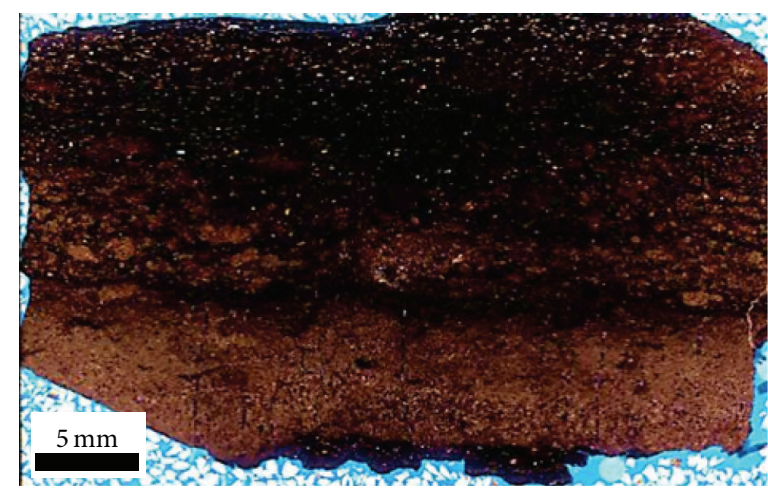

(d)

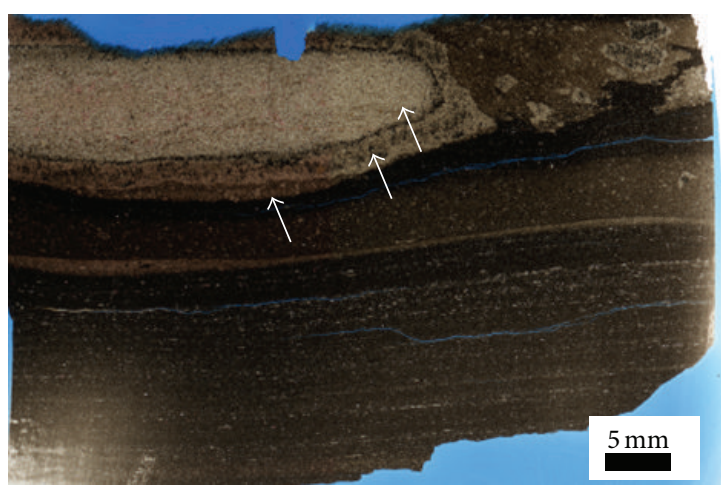

(e)

FIGURE 5: (a) Core photo shows reworked concretion (white arrows) associated with erosion surface with lower irregular contact and upper gradational contact. (b) Thin section photo shows large, transported subrounded concretions. (c) Thin section photo shows elongate, reworked concretions associated with irregular sharp erosional surface. (d) Thin section photo shows sandy-size reworked concretions. (e) Thin section photo shows reworked concretion with several core (white arrows) that rimmed with pyrite.

Typically these concretions are elongate, rounded, flat and/or irregular in shape (Figures 5(a), 5(b), and 5(c)), with a different internal grain size from the matrix ranging from a pebbly, sandy, and silty to a mud. (Figure 5(d)). Commonly concretions are light gray; however, black and dark brown concretions also occur. Interestingly, the concretions show more than one pyritized rim, indicating a multiphase origin (Figure 5(e)). The groundmass of the concretions varies between clay-rich mudstone (Figure 5(b)) and calcareousrich mudstone (Figure 5(c)). In most cases, concretions that occur are associated with thin intervals of densely packed shells and/or shell debris (Figure 5(c)).

4.3.2. Interpretation. The roundness of concretions, different lithology from the host sediment, and the soft deformation 


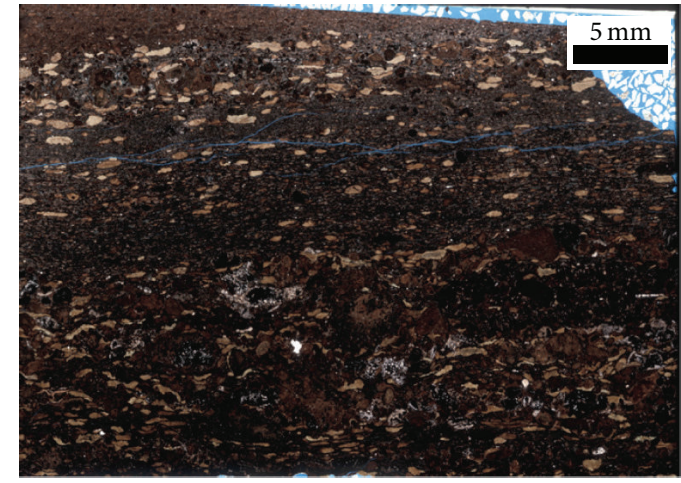

(a)

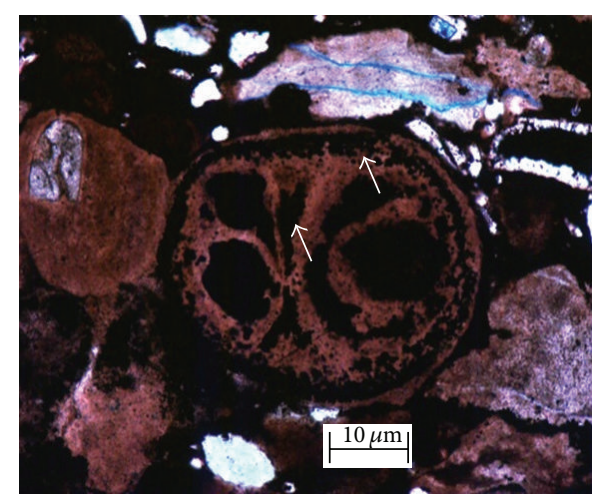

(b)

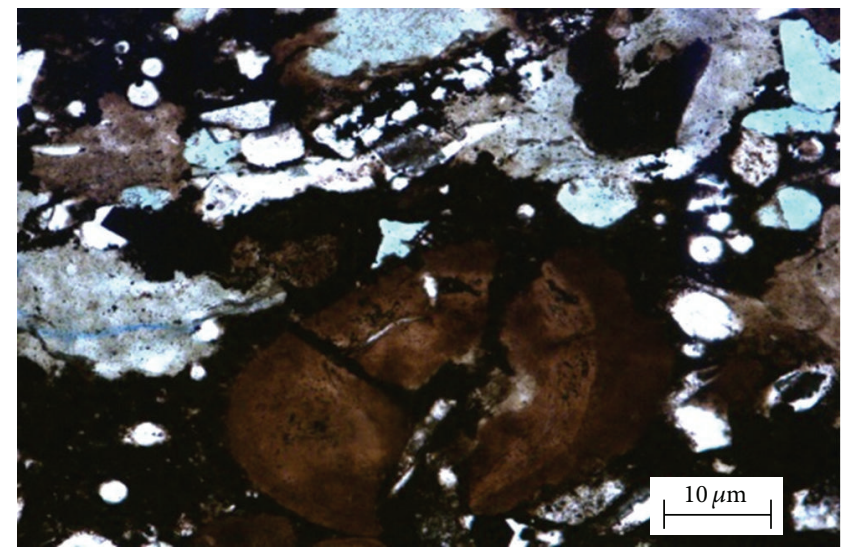

(c)

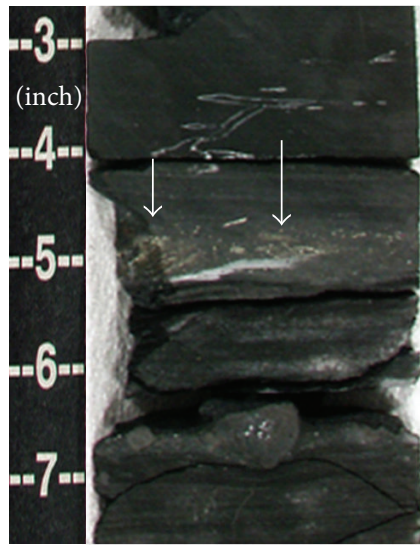

(d)

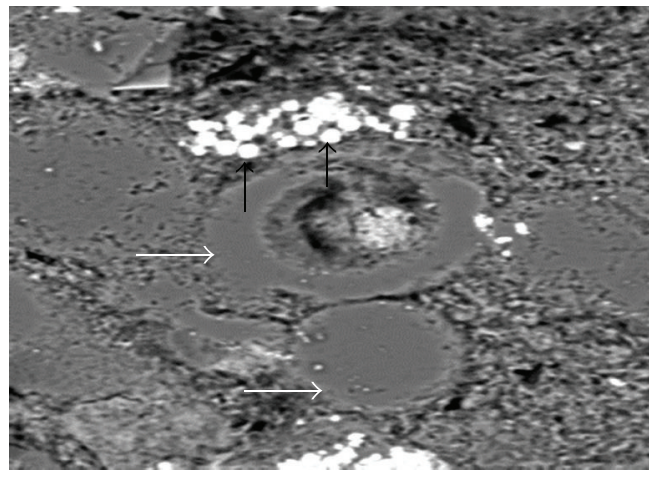

(e)

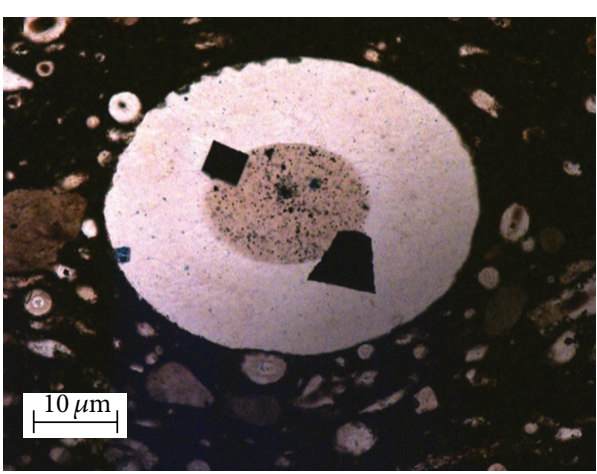

(f)

Figure 6: (a) Thin section photo shows concentration of phosphatic pellets associated with erosion surface. (b) Thin section photo shows rounded and subrounded phosphatic pellets; note the pyritic rim inside the phosphatic pellet (white arrows). (c) Thin section photo shows reworked broken phosphatic pellet associated with erosion surface. (d) Core photo shows the extensive pyrite cement of the erosion surface (white arrows). (e) Electron microprobe photo shows framboidal pyrite (black arrows) developed around sponge specula (white arrow) (photo dimensions is $527 \times 527 \mathrm{~mm}$ ). (f) Thin section photo shows fine euhedral pyrite crystal through the core of large sponge spicule associated with erosion surface.

structures in the underlying sediments suggest the reworking origin of these concretions. The occurrence of reworked concretions along erosional surfaces indicates formation at depths sufficiently shallow to be reworked by storms [23]. The dark brown color could be due to either phosphate and/or iron oxide impregnation; the latter might prevail due to the oxidation of pyrite in an oxic zone as a result of shallowing conditions. A storm event is one process that can rework concretions and is associated with a fining upward sequence afterstorm [27].

4.3.3. Description. The phosphatic pellets that are associated with erosion surfaces within the Barnett Shale are mostly brownish to black and range in size from few millimeters to 1 centimeter (Figure 6(a)). The pellets occur as rounded (Figure 6(b)) to subrounded, broken (Figure 6(c)), irregular, 
and rarely elongated with long axis parallel to bedding planes. The nuclei of these phosphatic grains may include shell fragments, detrital quartz, and glauconite grains.

4.3.4. Interpretation. The occurrence of phosphatic pellets is widely documented within the Barnett Shale $[9,28,29]$, so it is one of the most important constituents associated with the erosion surfaces. Phosphatic pellets are important indicators of extensive reworking of the underlying substrate. The nucleus of these pellets shows multiple coatings through extensive reworking and transporting processes. The size, roundness, and broken edges of the phosphatic pellets, which are associated with erosion surfaces, imply that the energy conditions were sufficiently high to erode materials from the underlying sediments and agitate individual particles forming pellets.

\subsection{Pyrite}

4.4.1. Description. Pyrite occurs in erosion surfaces dominantly (Figure 6(d)) as a conspicuous accessory component disseminated in most of the phosphatic pellets (Figure 6(b)), shale rip-up clasts (Figure 4(f)), and reworked concretions (Figure 5(e)). Pyrite is present mainly in the form of framboidal pyritic pellets that may aggregate to larger pellets (Figure 6(e)) and disseminated fine euhedral crystals (Figure 6(f)).

4.4.2. Interpretation. The presence of pyrite is an indication of geochemical conditions during and/or after development of erosion surface [18, 30-32]. Furthermore, pyrite indicates that the erosion surfaces resulting from major sea-level drop [7]. The abundance of fine crystalline pyrite in phosphatic pellets and shale intraclasts indicate deposition from an euxinic (anoxic and sulfidic) water column [30] and hence reducing depositional environment. Pyritization of a thick zone that has taken place beneath an erosion surface may represent a significant hiatus associated with the erosion event [33]. Pyrite framboids are characteristic of early diagenesis and crystallize in the water column, settle to the bottom, and cease to grow $[18,34]$.

\section{Origin of Erosion Surfaces}

Origin of erosion surfaces was the focus of several works; for example, Baird et al. [35] suggested internal waves during transgression. Allersma [36] and Rine and Ginsburg [37] proposed the migration of mud waves (mud banks) as an origin for erosion surfaces whereas wave scouring in front of an advancing shoreline is also an accepted origin for the regressive surface of marine erosion and ravinement surface [38, 39]. However, Schieber [7] refers to the origin of erosion surfaces in the Chattanooga Shale, storm-induced currents. However, strong bottom-current activity could be the reason for gravel lag formation as stated by Howe et al. [40]. Additionally, storm wave action can cause erosion of the sea floor as proposed by Caron et al. [24].
The erosion events in the Barnett Shale exhibit variable relief $(5-60 \mathrm{~mm})$, different geometry for upper and lower bounding contacts, and a wide range of erosional features with variable grain size above and below the surface (Table 1). Clearly, several factors control such variations, including the energy conditions, rate of relative sea-level fluctuation, rate of sedimentation, sediment influx, and the lithofacies type of the underlying bed [41-45].

Although, in most cases, sediment starvation condition is the favored interpretation for development of erosion surfaces in organic-rich shale [46-49], the detrital components associated with these surfaces were likely input to distal basin from the proximal shelf as a result of wave processes eroding and reworking the underlying deposits (Figure 7(a)) [50-52]. Furthermore, the lower sharp to irregular contacts associated with rounded to sub rounded intraclasts indicate that the sea bed was being reworked (Figure 7(b)), and consequently higher-energy conditions are suggested for the development of these surfaces than previously thought [22].

During periods of relative sea-level fall, the action of storm currents and waves possibly caused intensive winnowing and reworking of the underlying deep marine mudstones (Figure 7(a)) [8]. The resulting erosion surfaces which may remove the underlying regressive surface of erosion have commonly been interpreted as transgressive surface of erosion $[53,54]$.

\subsection{Shale Rip-Up Clasts}

5.1.1. Description. Rip-up clasts are muddy chunks that swept up from the preexisting sediments and are also termed mudstone clasts, intrabasinal clasts, or clay chips. The shale rip-up clasts appear mostly without internal structures and occur as materials eroded from the underlying lithofacies (Figures 4(e) and 4(f)). These clasts exhibit different shapes and sizes: rounded to subrounded (Figure $4(\mathrm{~g})$ ) but flat to sharp edges; flaky-like (Figure 4(e)) is the most characteristic feature for the shale rip-up clasts in the examined samples.

In some cases, the absence of erosion materials around erosion surfaces suggests either that these materials were transported to somewhere else in the basin, possibly by an unidirectional current strong enough to erode firm mud [1], or that the Barnett Shale was below the fairweather base level during a period of rapid rise of sea level which is insufficient time for sediment-water interaction [45]. However, the sharp to irregular erosion surface at the top of clay-rich shale facies (condensed section) (Figure 8(a)) may indicate that the erosion processes may have removed the expected, underlying, highstand lithofacies at this particular locality.

Because the Barnett Shale is mainly a clay-rich mudstone, thus the grain size variation of the substrate has little influence on the properties of the shale as in more proximal settings. However, the high energy conditions suggested for deposition of the Barnett Shale [2, 9, 18, 21] may generate erosion surfaces with high relief [45]. Noteworthy, the frequent occurrence of erosion surfaces throughout the Barnett Shale (Figure $8(\mathrm{~b})$ ) suggests that the episodic storm currents 


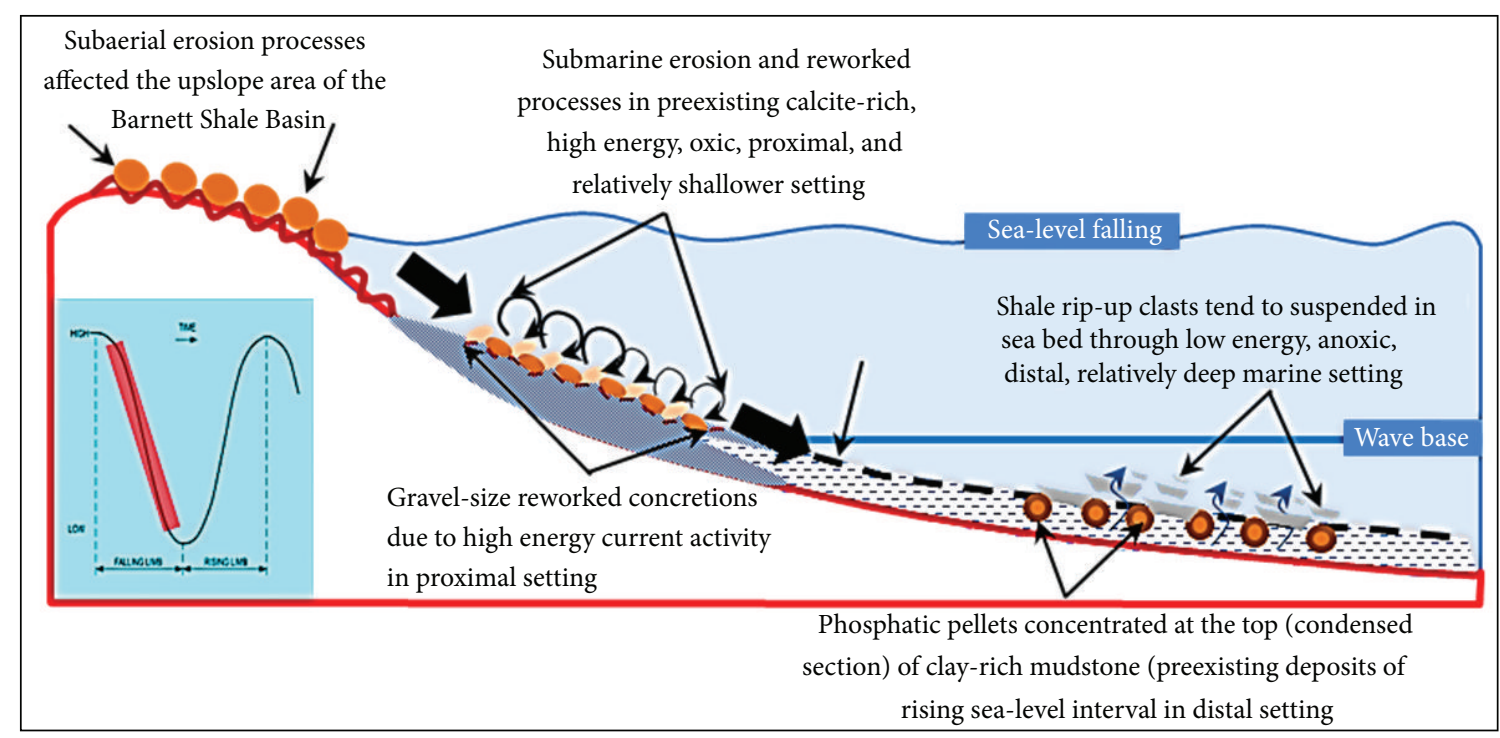

(a)

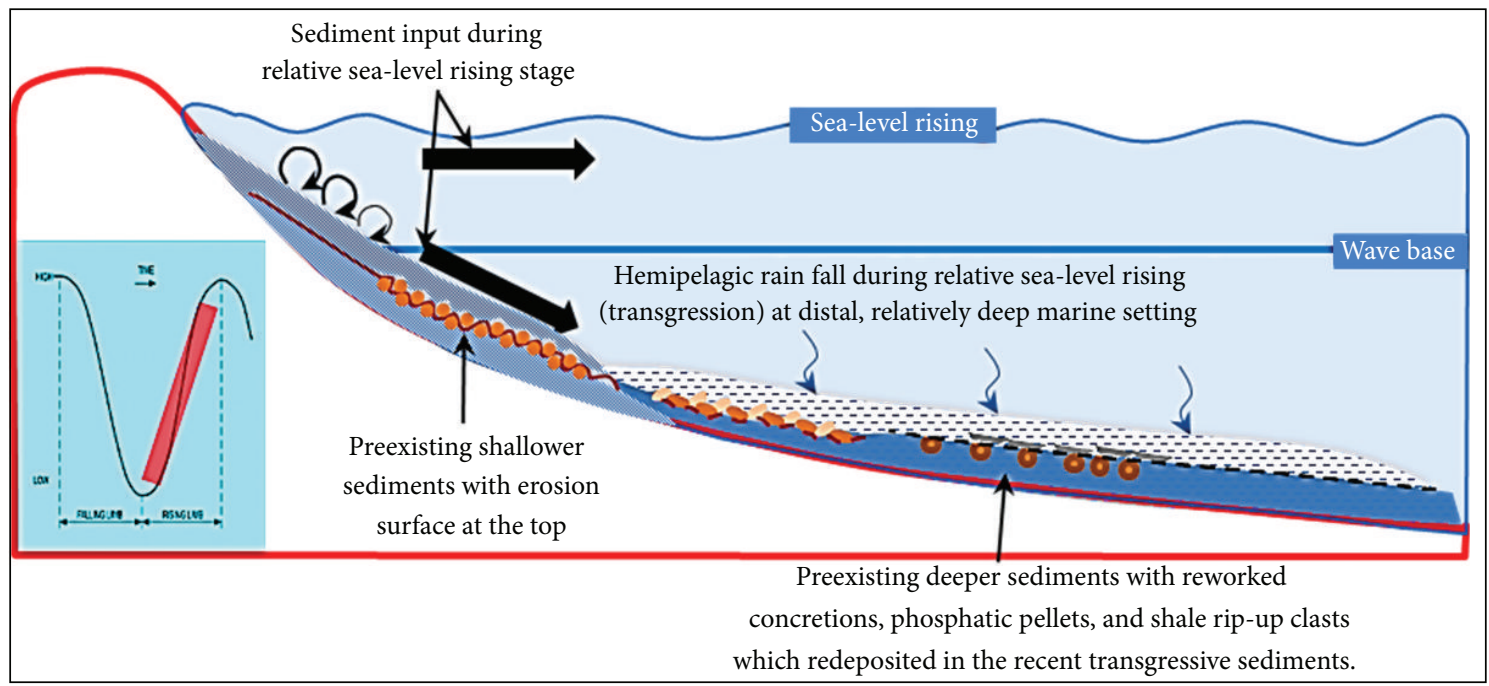

(b)

FIGURE 7: (a) Schematic diagram illustrates the development of erosion surface and their related features during relative sea-level fall in both proximal and distal muddy depositional settings. (b) Schematic diagram shows the transportation of the eroded and reworked materials down-dip during the relative sea-level rise to form erosion surface under the transgressive sediments.

and/or hyperpycnal flows are the major carriers for eroded and transported the erosional products from proximal to distal areas [2].

The development of erosion surfaces might have been influenced by water depth, sediment consistency, and slope where these conditions are expressed geologically as lateral facies changes associated with sedimentation breaks. The lateral variation from proximal (high energy preferred) to distal (low energy preferred) marine depositional settings can be indicated from the nature of erosion surfaces (Table 2). For example, the irregular nature, pebbly to sand size reworked intraclasts, reworked shelly laminae (Figure 8(c)), and the abundance of bioturbation indicate relatively shallower settings (Figures 7(a) and 7(b)), whereas sharp nature, shale rip-up clasts (Figure $8(\mathrm{~d})$ ), highly compacted shelly laminae, phosphatic-rich laminae, dolomitic and pyritic diagenetic cement, and the absence of bioturbation represent the relatively distal and deeper marine settings (Figures 7(a) and $7(b))$.

The significance of erosion surfaces within the organicrich Barnett Shale is not only that it aids regional sequence stratigraphic analysis $[9,29]$ but it also represents erosion of organic-rich muddy sediments so prediction of where these sediments have been re deposited should be considered as a future development target. 
TABLE 2: Characteristic features of erosion surfaces in both the proximal and the distal muddy settings.

\begin{tabular}{|c|c|c|}
\hline Characters & Proximal muddy settings & Distal muddy settings \\
\hline $\begin{array}{l}\text { Boundary } \\
\text { nature }\end{array}$ & Irregular, scoured, cutting down, gradational to irregular & Sharp to irregular \\
\hline Lithofacies & $\begin{array}{l}\text { Calcareous-rich mudstone facies with dolomitic } \\
\text { cementation }\end{array}$ & Clay-rich mudstone facies with pyritic cementation \\
\hline $\begin{array}{l}\text { Reworked } \\
\text { concretions }\end{array}$ & Rounded to subrounded calcareous shale intraclasts & Rounded to subrounded phosphatic pellets \\
\hline Shelly laminae & Reworked shell fragments & Compacted shelly laminae \\
\hline $\begin{array}{l}\text { Shale ripup } \\
\text { clasts }\end{array}$ & Rarely occurred & Elongated, flaky with sharp edges \\
\hline Energy levels & $\begin{array}{l}\text { High energy enough to include reworked shale intraclasts } \\
\text { and other components }\end{array}$ & $\begin{array}{l}\text { Low energy where the shale rip-up clasts are suspended in } \\
\text { the sea bed layer }\end{array}$ \\
\hline
\end{tabular}

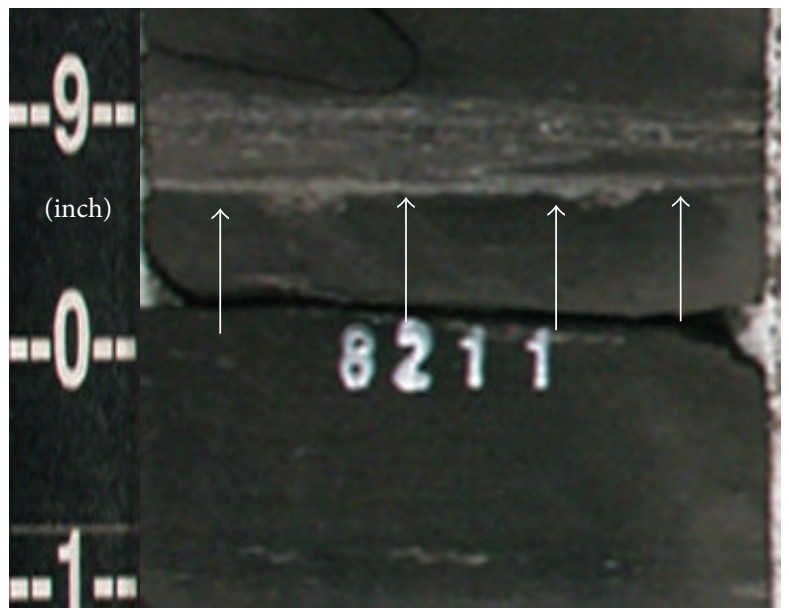

(a)

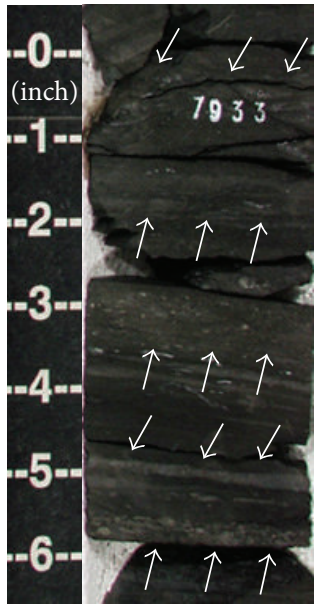

(b)

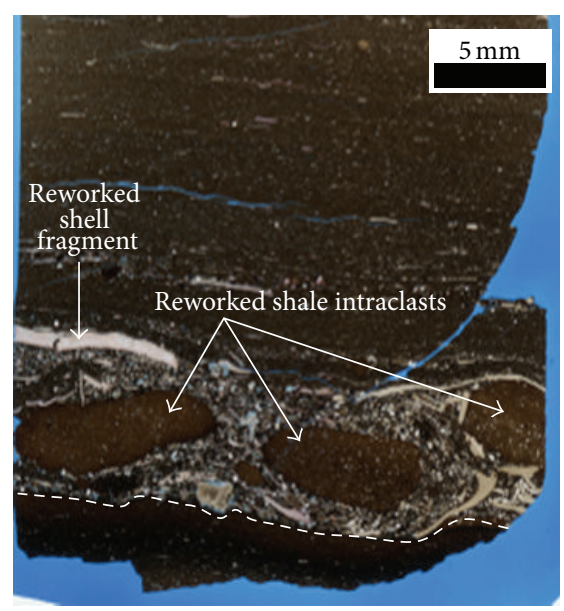

(c)

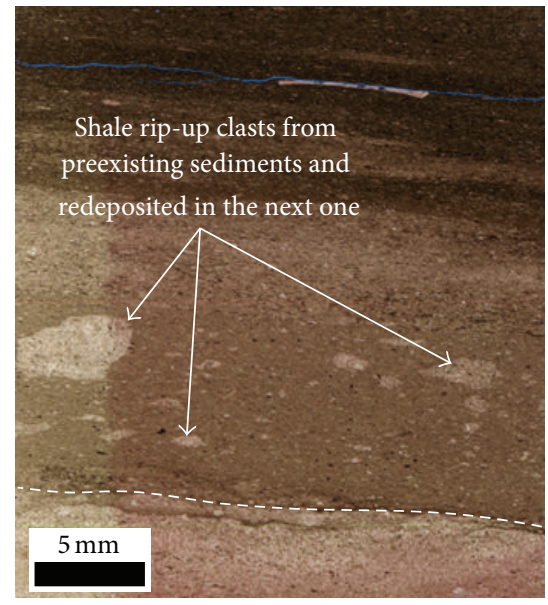

(d)

Figure 8: (a) Core photo shows sharp erosional contact at the topmost part of clay-rich mudstone facies. (b) Core photo shows multiple occurrence of erosional surfaces within less than one foot. (c) Thin section photo shows erosional surface and its related features indicated relatively proximal, shallow, and high energy muddy depositional setting (note the lower irregular contact (white dashed line), the pebbly-size reworked shale intraclasts, and reworked shell fragment). (d) Thin section photo shows erosional surface and its related features indicated relatively distal, deep, and low energy muddy depositional settings (note the lower sharp contact (white dashed line) and shale rip-up clasts). 


\section{Erosion Surfaces as Multiscale Stratigraphic Surfaces}

Since the accommodation space is likely available in the distal marine environments during the time intervals of relative sea-level fall and rise, then the identification of sequential events of deposition, nondepositions and/or erosion especially within fine-grained, organic-rich shale poses a unique challenge. However, the relative sea-level fluctuations are often expressed as subtle changes in bottom water oxygen levels, influx of terrigenous materials, biogenic productivity, and deposition of highly organic-looserich condensed sections [55]. The above discussed erosional features and their associated surfaces are candidates at least in part as boundaries between different genetic types of deposits [56] but on different scales depending on changes in baselevel and/or sediment supply. Subsequently, the studied erosion surfaces of the Barnett Shale reveal different strengths and/or duration which can be grouped into three different scales of stratigraphic surfaces including sequence-scale surfaces, parasequence-scale surfaces, and event-scale surfaces.

6.1. Sequence-Scale Erosion Surfaces. The sequence-scale erosional surfaces that result from a major erosional event [7] are the largest scale of the identified unconformable surfaces. This type of erosional surface is used to establish sequence stratigraphic framework for the Barnett Shale $[9,29]$. Such surfaces have relatively high relief (commonly $>25 \mathrm{~mm}$ and up to $60 \mathrm{~mm}$ ) and have an irregular sharp boundary associated with a sandy to silty pyritic lag (Figure 9(a)). The most distinctive features of the sequence-scale erosional surfaces are the rounded to subrounded, reworked, intraclasts and highly compacted, horizontally oriented, and shelly laminae (Figure 9(a)) and (Table 3).

The lithology underlying these surfaces are commonly siliceous noncalcareous mudstone (Figure 9(b)) or siliceous calcareous mudstone, whereas the overlying lithofacies show an increase in calcite content and an increasing grain size of the detrital components (Figure 9(b)). This lithological variation bounding the sequence-scale erosional surfaces reflect a lateral facies changes from clay rich to calcite rich and the vertical change from relatively deeper to relatively shallower facies which is interpreted as a major change in depositional conditions.

The sequence-scale erosional surfaces are characterized by an abrupt change on gamma ray log (Figures 9(a)-9(d)). In such a case, when the erosion surface coms at the base of upward increasing spectral gamma ray (SGR) interval (Figure 9(a)), then it is interpreted as transgressive surface of erosion (TSE) [9]. Alternatively, the erosion surface associated with abrupt decreasing in SGR values (Figure 9(b)) is a sequence boundary [21].

6.2. Parasequence-Scale Erosion Surfaces. The erosion surfaces at this scale represent a major shift in depositional settings accompanied by corresponding changes in environ- mental energy and sediment supply during either sea-level rise or fall [57]. Examples of changes in depositional trends include the change from sedimentation to erosion and/or starvation and vice versa and also the change from a regression to a transgression and vice versa [58].

The parasequences-scale erosion surfaces are characterized by medium relief (ranging between 8 and $20 \mathrm{~mm}$ ) with sharp to irregular contacts underlying with phosphatic-rich to clay-rich non calcareous mudstone facies (Figure 9(c)) of relatively deeper depositional environment and overlain with laminated calcareous-rich mudstone facies of relatively shallower depositional settings $[9,18,21]$. Additionally, this type of erosion surfaces represents the turnaround point on SGR curve as a result of the lithofacies change from clay, phosphatic-rich mudstone below to siliceous calcareous mudstone above these surfaces (Figure 9(c)) (Table 3). The parasequence-scale erosion surface may consistent with a marine flooding surface and/or maximum flooding surface which results from an abrupt increase in water depth $[59,60]$ when it is associated with shale rip-up clasts, traces of compacted and horizontally oriented shell fragments (Figure 9(d)) as well as diagenetic dolomite and pyrite.

6.3. Event-Scale Erosion Surfaces. These are the smallest scale types of erosional surfaces that mark changes in sedimentation regimes and may reflect minor or short-duration erosional events [7]. Such events are commonly distinguished by flat, low relief $(<5 \mathrm{~mm})$, sharp contacts, and shale on shale boundary with minimal evidence of erosion (Figure 10(a)) (Table 3 ). The sharp nature of these erosional surfaces is attributed to abrupt lithological changes and the presence of calcareous concretions at surfaces as a result of sediment starvation or a low sedimentation rate reflecting low depositional energy [61]. The lithofacies change is markedly around this type of erosional surface with subsequent deposition of siliceous non calcareous mudstone (Figure 10(b)) to a siliceous calcareous mudstone (Figure 10(c)). Generally, the high frequency and diversity of erosion surfaces through the Barnett Shale give a unique view into the short-duration stratigraphic intervals that were previously difficult to detect in fine grained rock.

6.4. Summary and Conclusion. The erosion surfaces are direct indications of major environmental changes that may include nondeposition and/or erosional events. The erosion surfaces are relatively abundant throughout the Barnett Shale which punctuate the stacking pattern and erode previously deposited strata to an unknown extent.

The erosion surfaces in the organic-rich Barnett Shale exhibit variable relief $(5-60 \mathrm{~mm})$ with different geometry of upper and lower bounding contacts and a wide range of variable features including shelly laminae, shale rip-up clasts, reworked intraclasts, phosphatic pellets, and diagenetic minerals (dolomite and pyrite). Several factors control such variations, including the energy conditions at deposition, rate of relative sea-level fluctuation, rate of sedimentation, sediment influx, and the lithofacies type of the underlying and 


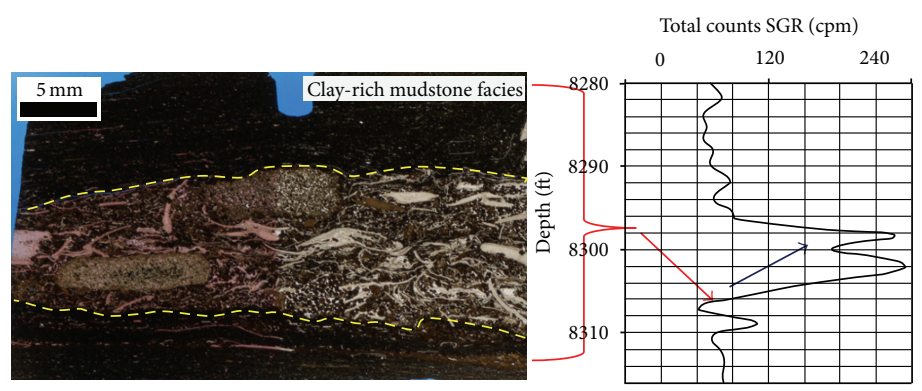

(a)

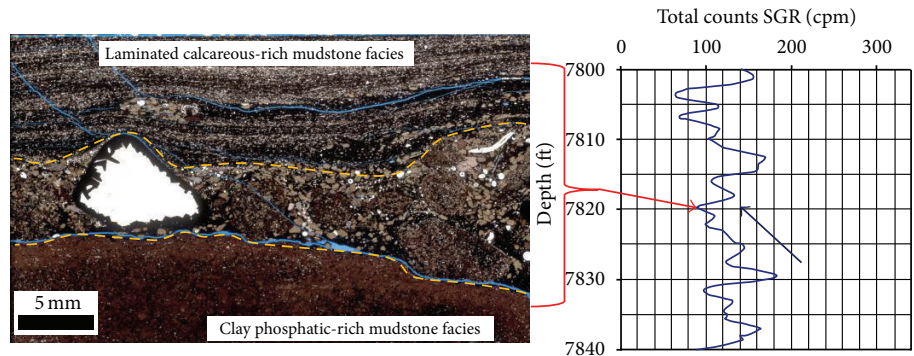

(b)
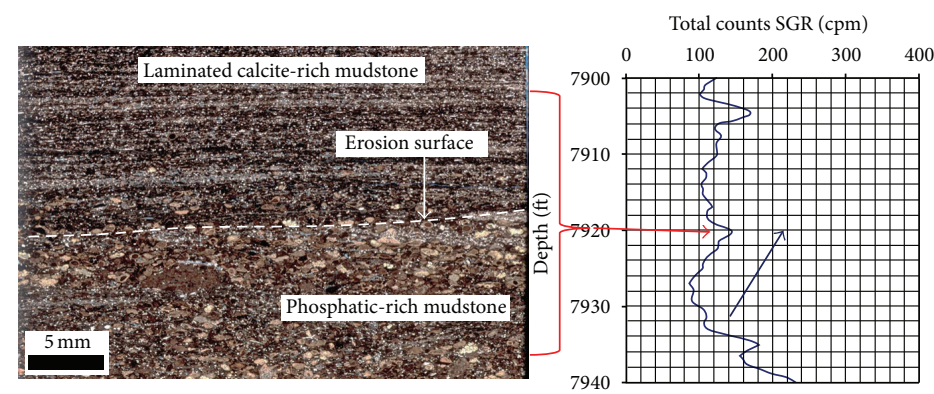

(c)

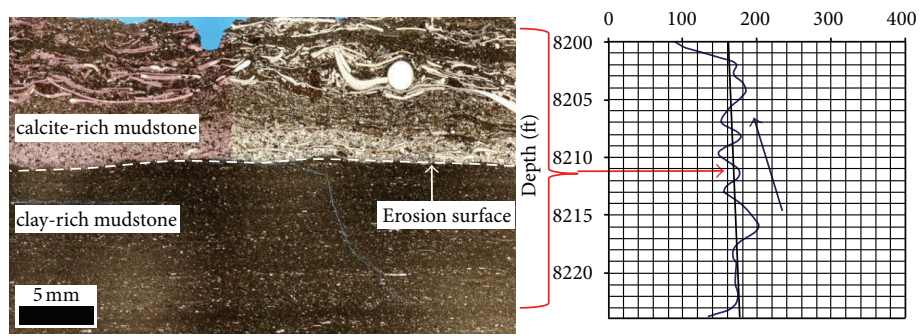

(d)

FIgURE 9: (a) Thin section photo shows sequence-scale erosion surface with irregular nature, pyritic reworked intraclasts, and reworked shell fragments with the opposite spectral gamma ray response that shows the abrupt upward increasing above the erosion surface. (b) Thin section photo shows irregular sequence-scale erosion surfaces; note the underlying clay phosphatic-rich facies and the overlying laminated calcareous facies. The opposite log is the spectral gamma ray value of this interval showing the coincide upward-decreasing pattern. (c) Thin section photo shows parasequence-scale erosion surface with underlying phosphatic-rich mudstone facies with the opposite Spectral Gamma Ray response that shows the upward decreasing above the erosion surface. (d) Thin section photo shows irregular parasequence-scale erosion surfaces; note the underlying clay phosphatic-rich facies and the overlying laminated calcareous facies. The opposite log is the spectral gamma ray value of this interval showing coinciding upward-decreasing pattern.

the overlying beds. The alternative occurrence of erosion surfaces throughout the Barnett Shale suggests episodic storm currents which transport eroded particles and intraclasts from proximal to distal areas.
The erosional features and associated surfaces are in part boundaries between different genetic types of deposits but on different scales reflecting the dependence on either base-level and/or sediment supply. Accordingly, the studied erosional 
TABLE 3: Characteristic features of multi-scale erosional surfaces.

\begin{tabular}{|c|c|c|c|}
\hline Characters & Sequence-scale erosion surface & Parasequence-scale erosion surface & $\begin{array}{c}\text { Event-scale erosion } \\
\text { surface }\end{array}$ \\
\hline Relief & More than $25 \mathrm{~mm}$ & Range between 8 and $20 \mathrm{~mm}$ & $<5 \mathrm{~mm}$ \\
\hline Surface nature & Irregular, scoured, cutting down & Sharp, irregular to gradational & Sharp \\
\hline Lithofacies & $\begin{array}{l}\text { siliceous non calcareous mudstone and } \\
\text { Siliceous calcareous mudstone }\end{array}$ & $\begin{array}{l}\text { Siliceous non calcareous mudstone and } \\
\text { Siliceous calcareous mudstone }\end{array}$ & $\begin{array}{l}\text { Clay-rich mudstone } \\
\text { facies }\end{array}$ \\
\hline $\begin{array}{l}\text { Reworked } \\
\text { concretions }\end{array}$ & Rounded to subrounded shale intraclasts & Subrounded phosphatic pellets & Calcareous concretions \\
\hline Shelly laminae & $\begin{array}{l}\text { Highly compacted and horizontally } \\
\text { oriented shell fragments }\end{array}$ & $\begin{array}{l}\text { Traces of thin disconnected shelly } \\
\text { laminae }\end{array}$ & Rarely occurred \\
\hline Shale rip-up clasts & Rarely occurred & Common & Rarely occurred \\
\hline $\begin{array}{l}\text { Spectral gamma ray } \\
\text { pattern }\end{array}$ & $\begin{array}{l}\text { Abrupt change (decreasing and } \\
\text { increasing) }\end{array}$ & $\begin{array}{l}\text { Marking the end of upward increasing or } \\
\text { decreasing spectral Gamma Ray pattern }\end{array}$ & Does not Apply \\
\hline Energy levels & $\begin{array}{l}\text { High energy enough to reworked shale } \\
\text { intraclasts and other components }\end{array}$ & $\begin{array}{l}\text { Low energy where the shale rip-up clasts } \\
\text { suspended in the sea bed layer }\end{array}$ & $\begin{array}{c}\text { Low bottom energy } \\
\text { levels }\end{array}$ \\
\hline
\end{tabular}

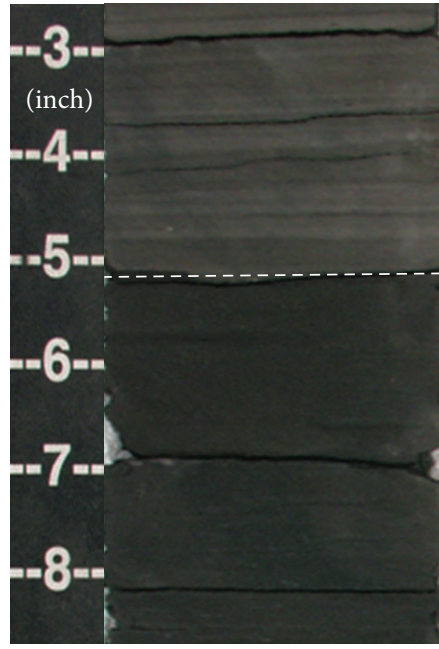

(a)

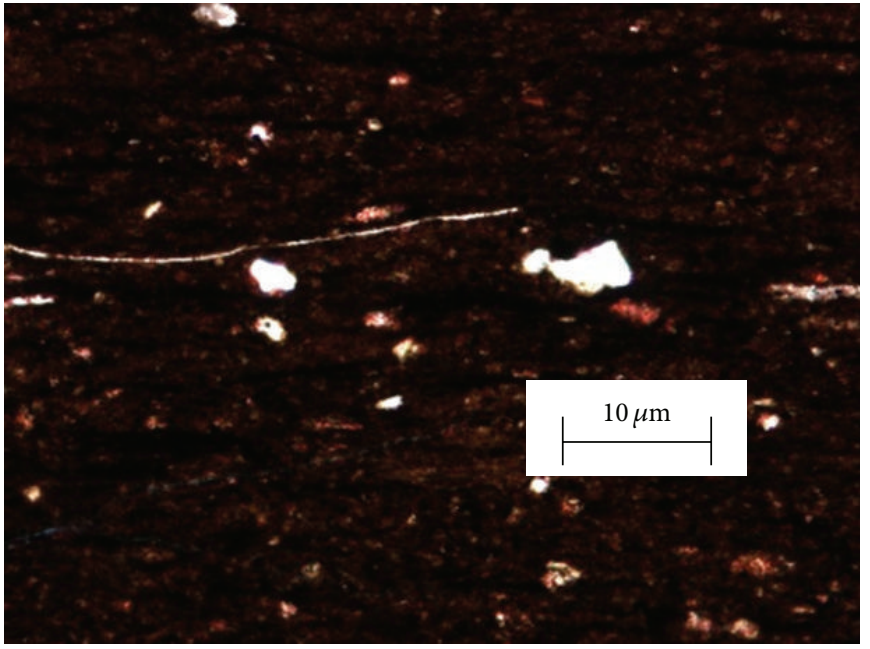

(b)

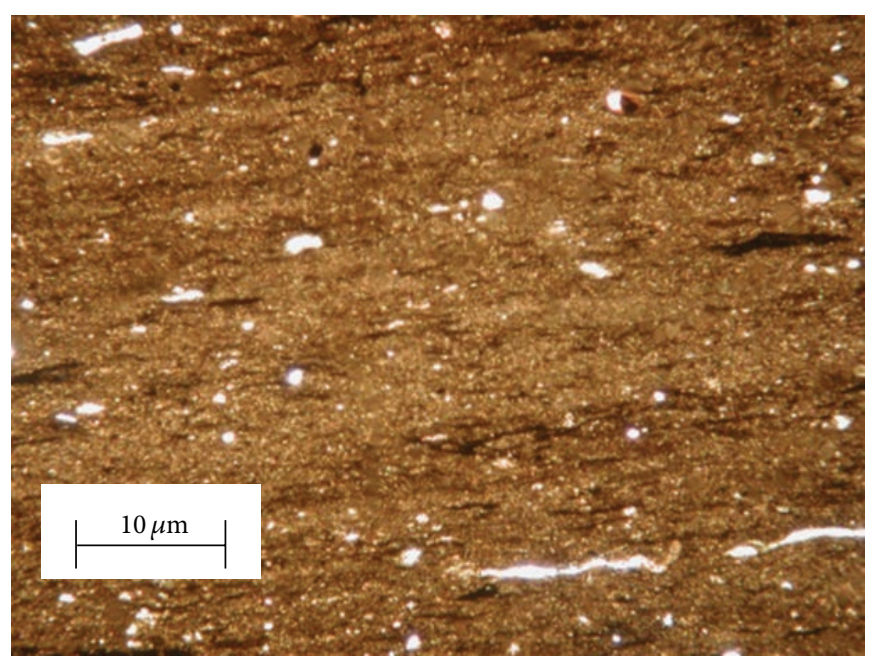

(c)

FIGURE 10: (a) Core photo shows an event-scale erosion surface with sharp nature (dashed line) between laminated black shale and an overlying dark laminated gray shale bed. (b) Thin section photo shows siliceous noncalcareous mudstone facies below the event-scale erosion surface in (a). (c) Thin section photo shows siliceous calcareous mudstone facies above the event-scale erosion surface in (a). 
surfaces of the Barnett Shale can be grouped into three different scales of sequence stratigraphic surfaces: sequencescale surfaces, parasequence-scale surfaces, and event-scale surfaces.

\section{Acknowledgments}

The author is thankful to the ConocoPhillips School of Geology and Geophysics, University of Oklahoma, where the labwork of this research has been conducted. The author is also thankful to the Faculty of Petroleum and Mining Engineering, Suez University, for providing the sabbatical leave. The constructive reviews and editorial comments of Roger M. Slatt, Gungoll Family Chair Professor of Petroleum Geology and Geophysics and Director of Reservoir Characterization Institute, University of Oklahoma, are gratefully acknowledged.

\section{References}

[1] J. Schieber, "Evidence for high-energy events and shallowwater deposition in the Chattanooga Shale, Devonian, central Tennessee, USA," Sedimentary Geology, vol. 93, no. 3-4, pp. 193208, 1994.

[2] M. O. Abouelresh and R. M. Slatt, "Shale depositional processes: example from the paleozoic Barnett Shale, Fort Worth Basin, Texas, USA," Central European Journal of Geoscience, vol. 3, no. 4, pp. 398-409, 2011.

[3] W. J. Kennedy and H. C. Klinger, "Hiatus-concretions and hardground horizons in the Cretaceous of Zululand," Paleontology, pp. 539-549, 1972.

[4] W. J. Kennedy and R. E. Garrison, "Morphology and genesis of nodular chalks and hardgrounds in the Upper Cretaceous of Southern England," Sedimentology, vol. 22, pp. 311-386, 1975.

[5] W. J. Kennedy and R. E. Garrison, "Morphology and genesis of nodular phosphates in the Cenomanian Glauconitic Marl of southeast England," Lethaia, vol. 8, pp. 339-360, 1975.

[6] G. C. Baird, "Pebbly phosphorites in shale, a key to recognition of a widespread submarine discontinuity in the Middle Devonian of New York," Journal of Sedimentary Petrology, vol. 2, pp. 545-555, 1978.

[7] J. Schieber, "Sedimentary features indicating erosion, condensation, and hiatuses in the Chattanooga Shale of Central Tennessee: relevance for sedimentary and stratigraphic evolution," in Shales and Mudstones, J. Schieber, W. Zimmerle, and P. Sethi, Eds., vol. 1, pp. 187-215, 1998.

[8] D. Nummedal and D. J. P. Swift, "Transgressive stratigraphy at sequence-bounding unconformities: some principles derived from Holocene and Cretaceous examples," in Sea-Level Fluctuation and Coastal Evolution, D. Nummedal, O. H. Pilkey, and J. D. Howard, Eds., vol. 42, pp. 358-370, SEPM Special Publication, 1987.

[9] M. O. Abouelresh and R. M. Slatt, "Lithofacies and sequence stratigraphy of the Barnett Shale in east-central Fort Worth Basin, Texas," AAPG Bulletin, vol. 96, no. 1, pp. 1-22, 2012.

[10] S. L. Montgomery, D. M. Jarvie, K. A. Bowker, and R. M. Pollastro, "Mississippian Barnett Shale, Fort Worth basin, northcentral Texas: Gas-shale play with multi-trillion cubic foot potential," AAPG Bulletin, vol. 89, no. 2, pp. 155-175, 2005.
[11] P. T. Flawn, A. Goldstein Jr., P. B. King, and C. E. Weaver, "The Ouachita system: University of Texas, Bureau of Economic Geology," Report 6120, 1961.

[12] J. L. Walper, "Plate tectonic evolution of the Fort Worth Basin," in Petroleum Geology of the Fort Worth Basin and Bend Arch Area, C. A. Martin, Ed., pp. 237-251, Dallas Geological Society, Dallas, Tex, USA, 1982.

[13] J. K. Arbenz, "Structure framework of the ouachita mountains," in Stratigraphic and Structural Evolution of the Ouachita Mountains and Arkoma Basin, Southeastern Oklahoma and WestCentral Arkansas: Application To Petroleum Exploration, N. H. Suneson, Ed., pp. 4-40, Oklahoma Geological Survey, Circular, 2009.

[14] J. D. Henry, "Stratigraphy of the Barnett Shale (Mississippian) and associated reefs in the northern Fort Worth Basin," in Petroleum Geology of the Fort Worth Basin and Bend Arch Area, C. A. Martin, Ed., pp. 157-178, Dallas Geological Society, Dallas, Tex, USA, 1982.

[15] J. W. Flippin, "The stratigraphy, structure, and economic aspects of the Paleozoic strata in Erath County, north central Texas," in Petroleum Geology of the Fort Worth Basin and Bend Arch Area, C. A. Martin, Ed., pp. 129-155, Dallas Geological Society, Dallas, Tex, USA, 1982.

[16] R. S. Kier, L. F. Brown, and E. F. McBride, The Mississippian and Pennsylvanian (Carboniferous) Systems in the United States: Texas, vol. 14, Bureau of Economic Geology, University of Texas at Austin, Geological Circular, Austin, Texas, 1980.

[17] W. J. Mapel, R. B. Johnson, G. O. Bachman, and K. L. Varnes, "Southern midcontinent and southern Rocky Mountains region," in Paleotectonic Investigations of the Mississippian System in the United States, L. C. Craig and C. W. Connor, Eds., vol. 1010, pp. 161-187, Geological Survey Professional Paper, 1979.

[18] R. G. Loucks and S. C. Ruppel, "Mississippian Barnett Shale: Lithofacies and depositional setting of a deep-water shale-gas succession in the Fort Worth Basin, Texas," AAPG Bulletin, vol. 91, no. 4, pp. 579-601, 2007.

[19] H. D. Rowe, R. G. Loucks, S. C. Ruppel, and S. M. Rimmer, "Mississippian Barnett Formation, Fort Worth Basin, Texas: Bulk geochemical inferences and Mo-TOC constraints on the severity of hydrographic restriction," Chemical Geology, vol. 257, no. 1-2, pp. 16-25, 2008.

[20] B. U. Haq and S. R. Schutter, "A chronology of paleozoic sealevel changes," Science, vol. 322, no. 5898, pp. 64-68, 2008.

[21] P. Singh, Lithofacies and sequence-stratigraphic framework of the Barnett Shale, northeast Texas [Ph.D. thesis], University of Oklahoma, Norman, Oklahoma, 2008.

[22] J. Macquaker, "Micro-Textural Analyses of Fine-Grained Sediments and the Roles that Advective Sediment Transport and Suspension Settling Processes Play in the Deposition of FineGrained Organic Carbon-Rich Sediments. OR Just How Shaky are the Current Depositional Models that Seek to Explain the Origin of Source Rocks / shale Gas Reservoirs?" in Proceedings of the Critical assessment of shale resource plays (ex. abs.), American Association Of Petroleum Geologists/Society of Economic Geologists/Society of Petroleum Geologists/Society of Petrophysicists and Well-Log Analysis Hedberg Conference, Austin, Texas, USA, December 2010.

[23] P. E. Potter, J. B. Maynard, and P. J. Depetris, Mud and Mudstones: Introduction and Overview, Springer, Berlin, Germany, 2005.

[24] V. Caron, C. S. Nelson, and P. J. J. Kamp, "Transgressive surfaces of erosion as sequence boundary markers in cool-water shelf 
carbonates," Sedimentary Geology, vol. 164, no. 3-4, pp. 179-189, 2004.

[25] A. P. Heward, "A review of wave-dominated clastic shoreline deposits," Earth Science Reviews, vol. 17, no. 3, pp. 223-276, 1981.

[26] S. M. Kidwell, "The stratigraphy of shell concentrations," in Taphonomy, Releasing the Data Locked in the Fossil Record, P. A. Allison and D. E. G. Briggs, Eds., pp. 211-290, Plenum, New York, NY, USA, 1991.

[27] F. T. Fursich, W. Oschmann, I. B. Singh, and A. K. Jaitly, "Hardgrounds, reworked concretion levels and condensed horizons in the Jurassic of western India: their significance for basin analysis," Journal of Geological Society, vol. 149, no. 3, pp. 313331, 1992.

[28] J. J. Hickey and B. Henk, "Lithofacies summary of the Mississippian Barnett Shale, Mitchell 2 T.P. Sims well, Wise County, Texas," AAPG Bulletin, vol. 91, no. 4, pp. 437-443, 2007.

[29] P. Singh, R. M. Slatt, G. Borges et al., "Reservoir characterization of unconventional gas shale reservoirs: example from the Barnett Shale, Texas, U.S.A," Oklahoma City Geological Society Shale Shaker, vol. 60, no. 1, pp. 15-31, 2009.

[30] R. T. Wilkin, H. L. Barnes, and S. L. Brantley, "The size distribution of framboidal pyrite in modern sediments: an indicator of redox conditions," Geochimica et Cosmochimica Acta, vol. 60, no. 20, pp. 3897-3912, 1996.

[31] R. T. Wilkin, M. A. Arthur, and W. E. Dean, "History of watercolumn anoxia in the Black Sea indicated by pyrite framboid size distributions," Earth and Planetary Science Letters, vol. 148, no. 3-4, pp. 517-525, 1997.

[32] D. Bond, P. B. Wignall, and G. Racki, "Extent and duration of marine anoxia during the Frasnian-Famennian (Late Devonian) mass extinction in Poland, Germany, Austria and France," Geological Magazine, vol. 141, no. 2, pp. 173-193, 2004.

[33] K. L. Bann, C. R. Fielding, J. A. MacEachern, and S. C. Tye, "Differentiation of estuarine and offshore marine deposits using integrated ichnology and sedimentology: Permian Pebbly Beach Formation, Sydney Basin, Australia," in The Application of Ichnology To Palaeoenvironmental and Stratigraphic Analysis, D. McIlroy, Ed., vol. 228, pp. 179-211, Geological Society, London, UK, 2004.

[34] J. P. Herbin, C. Muller, J. R. Geyssant, F. Melieres, I. E. Penn, and Y. Group, "Variation of the distribution of organic matter within a transgressive system tract: Kimmeridge Clay (Jurassic), England," in Source Rocks in a Sequence Stratigraphic Framework, B. J. Katz and L. M. Pratt, Eds., vol. 37, pp. 67-100, The American Association of Petroleum Geologists, 1993.

[35] G. C. Baird, C. E. Brett, and W. T. Kirchgasser, "Genesis of black shale-roofed discontinuities in the Devonian Genesee Formation, Western New York State," in Devonian of the World, N. J. McMillan, A. F. Embry, and D. J. Glass, Eds., vol. 2, pp. 357-375, Canadian Society of Petroleum Geologists, Calgary, Canada, 1988.

[36] E. Allersma, "Mud on the oceanic shelf of Guiana," in Proceedings of the Symposium on Investigation and Resources of the Caribbean Sea and Adjacent Regions, pp. 193-203, UNESCO, Paris, France.

[37] J. M. Rine and R. N. Ginsburg, "Depositional facies of a mud shoreface in Suriname, South America: a mud analogue to sandy, shallow-marine deposits," Journal of Sedimentary Petrology, vol. 55, no. 5, pp. 633-652, 1985.

[38] A. G. Plint, "Sharp-based shoreface sequences and "offshore bars" in the Cardium Formation of Alberta, their relationship to relative changes in sea level," in Sea Level Changes: An Integrated Approach, C. K. Wilgus, B. S. Hastings, C. G. St. C. Kendall, H. W. Posamentier, C. A. Ross, and J. C. Van Wagoner, Eds., vol. 42, pp. 357-370, SEPM Special Publication, 1988.

[39] D. Nummedal, G. W. Riley, and P. L. Templet, "High-resolution sequence architecture: a chronostratigraphic model based on equilibrium profile studies," in Sequence Stratigraphy and Facies Association, H. Posamentier, C. P. Summerhayes, B. U. Haq, and C. P. Allen, Eds., vol. 18, pp. 55-68, SEPM Special Publication, 1993.

[40] J. A. Howe, M. S. Stoker, and K. J. Woolfe, "Deep-marine seabed erosion and gravel lags in the northwestern Rockall Trough, North Atlantic Ocean," Journal of the Geological Society, vol. 158, no. 3, pp. 427-438, 2001.

[41] J. A. MacEachern, B. A. Zaitlin, and S. G. Pemberton, "Highresolution sequence stratigraphy of early transgressive deposits, Viking Formation, Joffre Field, Alberta, Canada," AAPG Bulletin, vol. 82, no. 5 A, pp. 729-756, 1998.

[42] S. A. J. Pattison, "Sequence stratigraphic significance of sharpbased lowstand shoreface deposits, Kenilworth Member, Book Cliffs, Utah,” AAPG Bulletin, vol. 79, no. 3, pp. 444-462, 1995.

[43] S. M. Kidwell and P. J. Brenchley, "Patterns in bioclastic accumulation through the Phanerozoic: changes in input or in destruction?" Geology, vol. 22, no. 12, pp. 1139-1143, 1994.

[44] R. G. Walker, "Sedimentary and tectonic origin of a transgressive surface of erosion: Viking Formation, Alberta, Canada," Journal of Sedimentary Research B, vol. 65, pp. 209-221, 1995.

[45] I. G. Hwang and P. L. Heller, "Anatomy of a transgressive lag: Panther Tongue Sandstone, Star Point Formation, central Utah," Sedimentology, vol. 49, no. 5, pp. 977-999, 2002.

[46] A. Hallam, "Eustatic cycles in the Jurassic," Palaeogeography, Palaeoclimatology, Palaeoecology, vol. 23, pp. 1-32, 1978.

[47] M. Elrick and J. F. Read, "Cyclic ramp-to-basin carbonate deposits, Lower Mississippian, Wyoming and Montana: a combined field and computer modeling study," Journal of Sedimentary Petrology, vol. 61, no. 7, pp. 1194-1224, 1991.

[48] P. B. Wignall and J. R. . Maynard, "The sequence stratigraphy of transgressive black shales," in Source Rocks in a Sequence stratigraphic framework, B. J. Katz and L. Pratt, Eds., vol. 37, pp. 35-47, The American Association of Petroleum Geologists, Studies in Geology, 1993.

[49] P. B. Wignall, Black Shales, Clarendon Press Oxford, 1994.

[50] D. J. P. Swift and J. A. Thorne, "Sedimentation on continental margins I: a general model for shelf sedimentation," in Shelf Sand and Sandstone Bodies, D. J. P. Swift, G. F. Oertel, R. W. Tillman, and J. A. Thorne, Eds., vol. 14, pp. 3-31, International Association of Sedimentologists, 1991.

[51] D. J. P. Swift, S. Phillips, and J. A. Thorne, "Sedimentation on continental margins I: a general model for shelf sedimentation," in Shelf Sand and Sandstone Bodies, D. J. P. Swift, G. F. Oertel, R. W. Tillman, and J. A. Thorne, Eds., vol. 14, pp. 153-187, International Association of Sedimentologists, 1991.

[52] R. G. Walker and A. G. Plint, "Wave- and storm-dominated shallow marine systems," in Facies Models: Response To Sea Level Change, R. G. Walker and N. P. James, Eds., pp. 219-238, Geological Association of Canada, 1992.

[53] J. P. Bhattarcharya, "The expression and interpretation of marine flooding surfaces and erosional surfaces in core, examples from the upper Cretaceous Dunvegan Formation, Alberta Foreland basin, Canada," in Sequence Stratigraphy and Facies Associations, H. W. Posamentier, C. P. Summerhayes, B. U. 
Haq, and G. P. Allen, Eds., vol. 18 of International Association of Sedimentologists, Special Publication, pp. 125-160, Blackwell Publishing, 1993.

[54] A. F. Embry, "Sequence boundaries and sequence hierarchies: problems and proposals," in Sequence Stratigraphy: Advances and Applications for Exploration and Production in Northwest Europe. Stavanger, R. J. Steel, V. L. Felt, E. P. Johannesen, and C. Mathieu, Eds., pp. 1-11, Elsevier, Amsterdam, The Netherlands, 1995.

[55] K. M. Husley, Lithofacies characterization and sequence stratigraphic framework for some gas-bearing shales within the Horn River Basin, Northeastern British Colombia [M.S. thesis], University of Oklahoma, Norman, Oklahoma, 2011.

[56] O. Catuneanu, V. Abreu, J. P. Bhattacharya et al., "Toward the standardization of the sequence stratigraphy," Earth-Science Reviews, vol. 92, no. 1-2, pp. 1-33, 2009.

[57] O. Catuneanu, Principles of Sequence Stratigraphy, Elsevier, Amsterdam, The Netherlands, 2006.

[58] A. Embry, E. Johannessen, D. Owen, B. Beauchamp, and P. Gianolla, "Sequence stratigraphy as a "Concrete" stratigraphic discipline," Report of the ISSC Task Group on Sequence Stratigraphy, 2007.

[59] K. M. Bohacs and J. R. Schwalbach, "Sequence stratigraphy of fine-grained rocks with special reference to the Monterey Formation," in Sequence Stratigraphy in Fine-Grained Rocks: Examples From the Monterey Formation, J. R. Schwalbach and K. M. Bohacs, Eds., vol. 70, Pacific Section SEPM Guidebook, 1992.

[60] M. R. Slatt, Stratigraphic Reservoir Characterization for Petroleum Geologists, Geophysicists, and Engineers, Elsevier, 2006.

[61] R. Raiswell and D. E. Canfield, "Sources of iron for pyrite formation in marine sediments," The American Journal of Science, vol. 298, no. 3, pp. 219-245, 1998. 

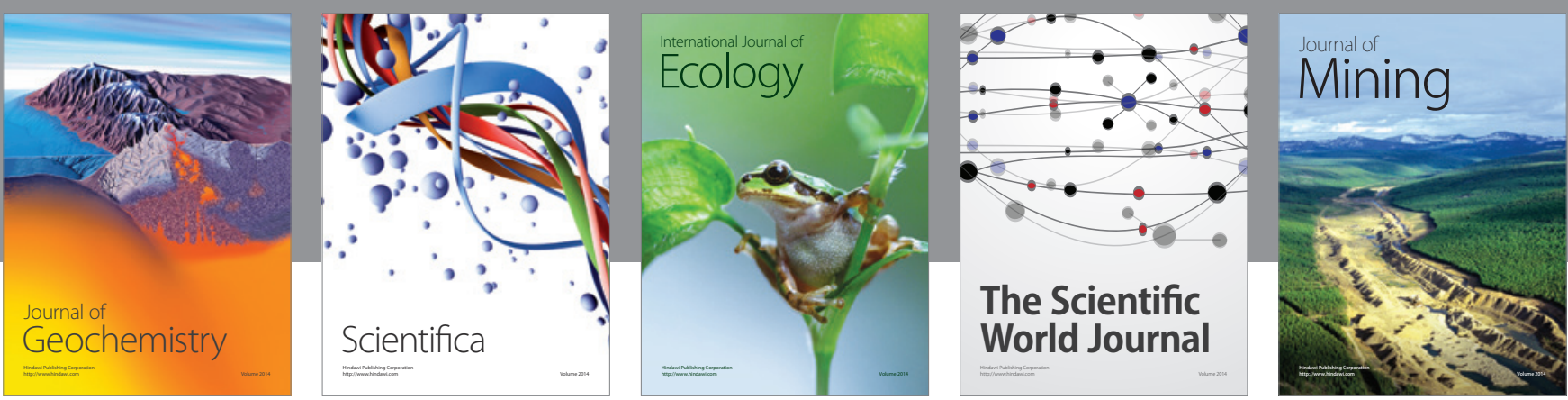

The Scientific World Journal
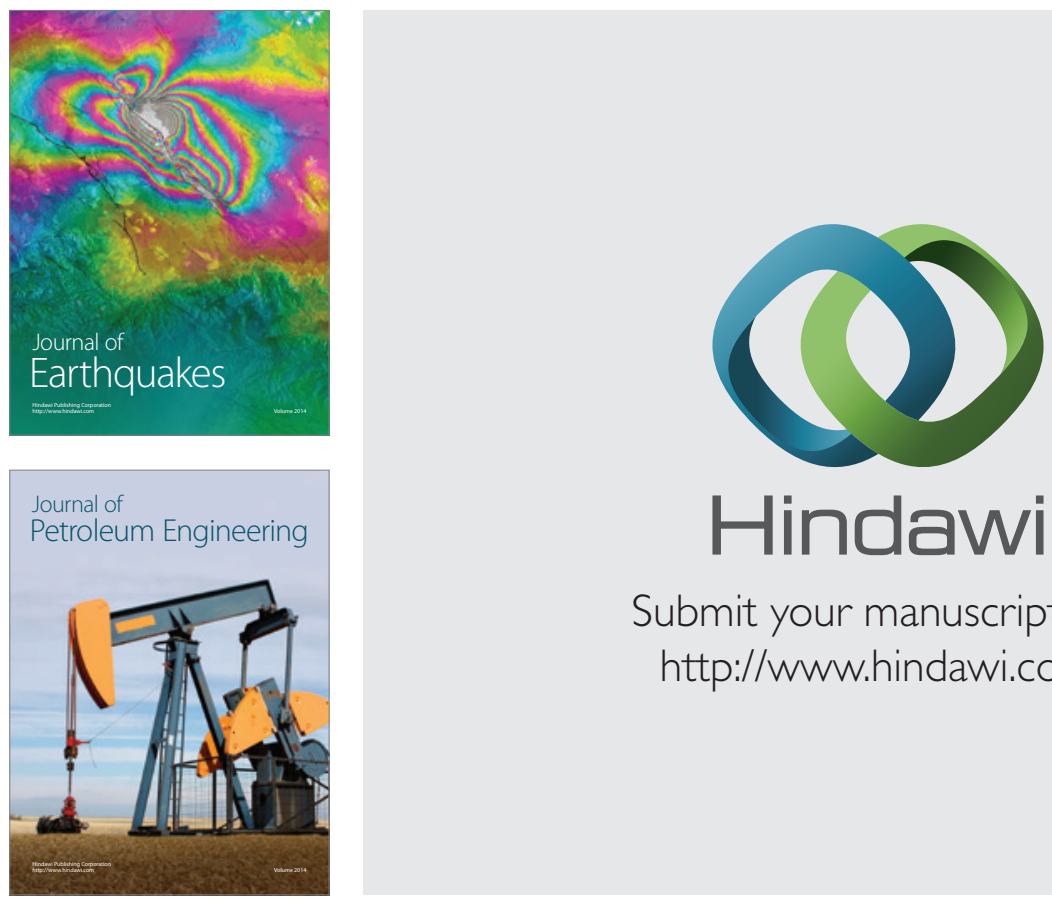

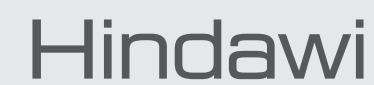

Submit your manuscripts at

http://www.hindawi.com
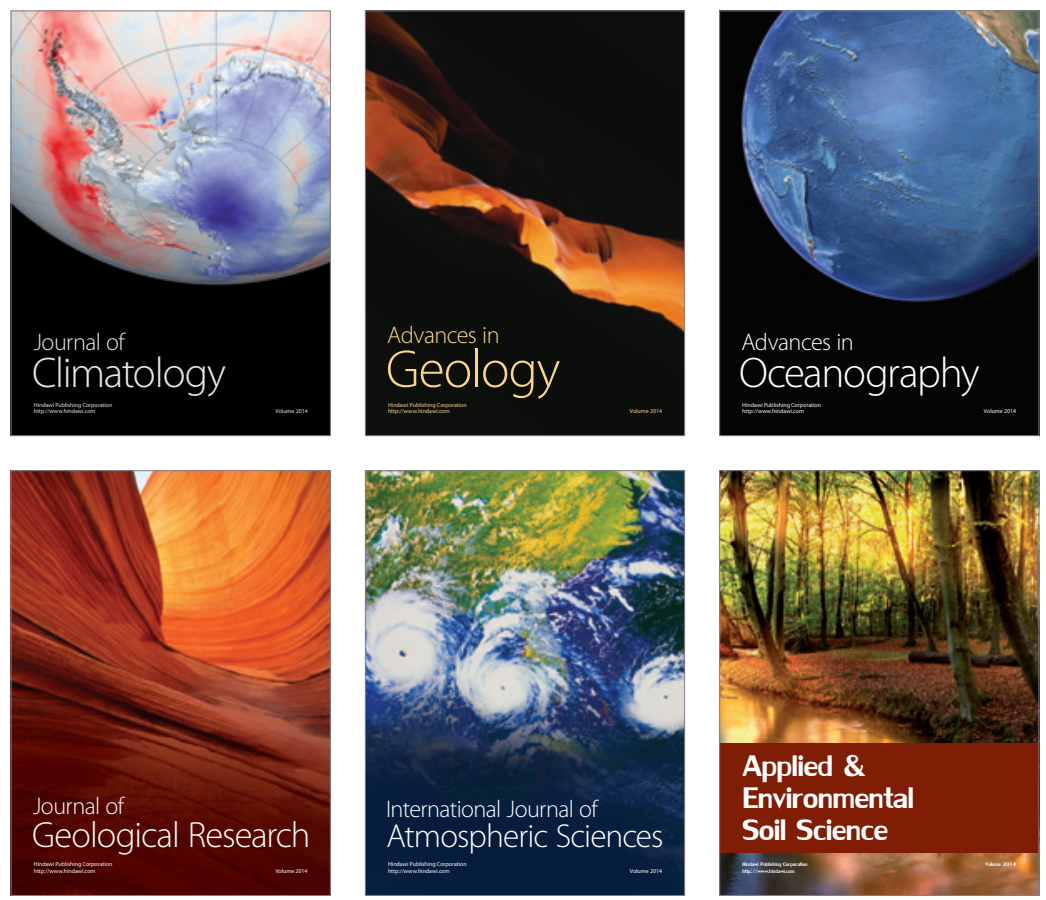
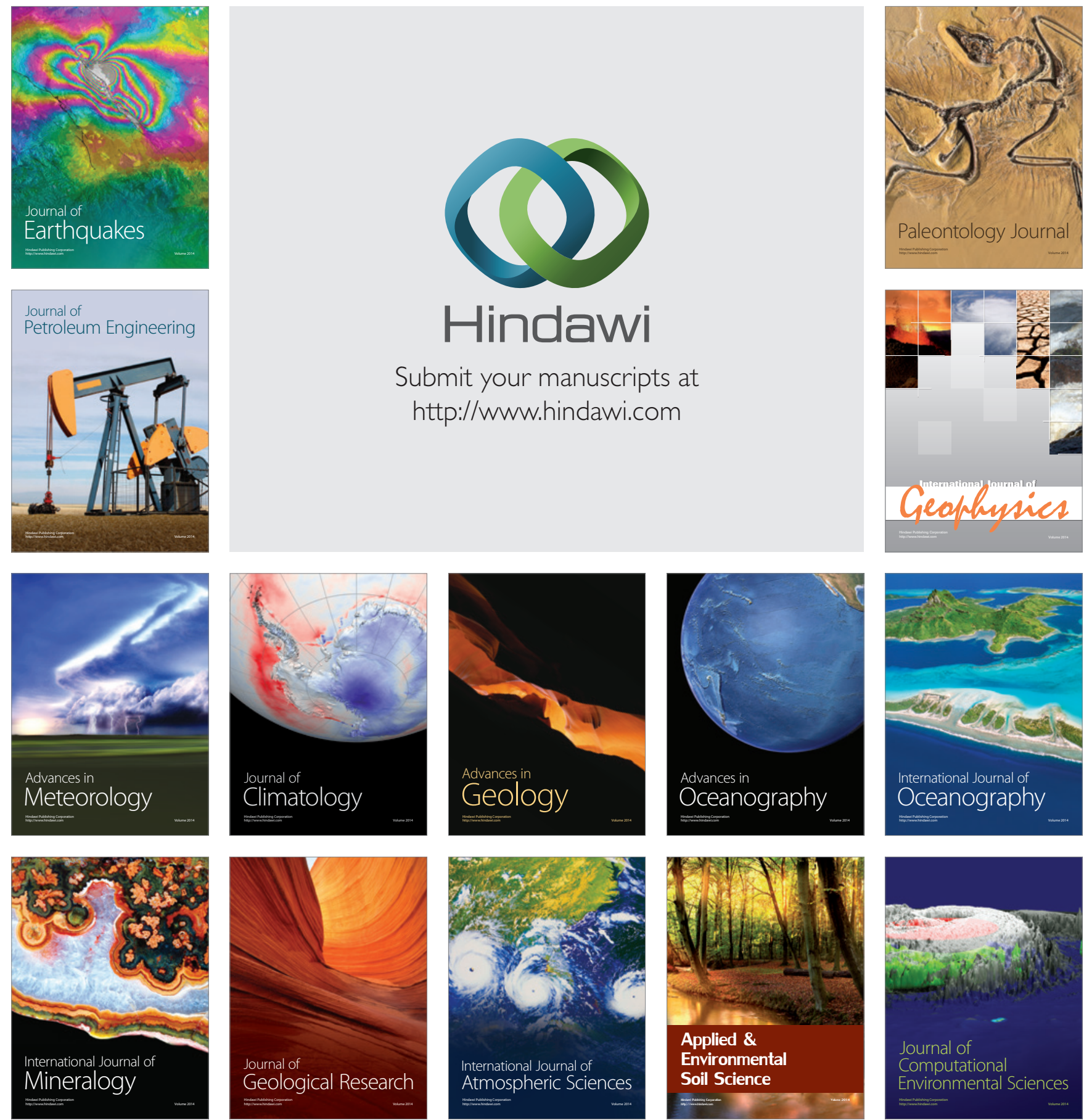